\title{
GCU
}

Glasgow Caledonian

University

University for the Common Good

\section{An eco-critical perspective on business models: the value triangle as an approach to closing the sustainability gap}

Biloslavo, Roberto; Bagnoli, Carlo; Edgar, David

Published in:

Journal of Cleaner Production

DOI:

10.1016/j.jclepro.2017.10.281

Publication date:

2017

Document Version

Author accepted manuscript

Link to publication in ResearchOnline

Citation for published version (Harvard):

Biloslavo, R, Bagnoli, C \& Edgar, D 2017, 'An eco-critical perspective on business models: the value triangle as an approach to closing the sustainability gap', Journal of Cleaner Production, vol. 174, pp. 746-762.

https://doi.org/10.1016/j.jclepro.2017.10.281

\section{General rights}

Copyright and moral rights for the publications made accessible in the public portal are retained by the authors and/or other copyright owners and it is a condition of accessing publications that users recognise and abide by the legal requirements associated with these rights.

Take down policy

If you believe that this document breaches copyright please view our takedown policy at https://edshare.gcu.ac.uk/id/eprint/5179 for details of how to contact us. 


\title{
An Eco-Critical Perspective on Business Models: The Value Triangle as an Approach to Closing the Sustainability Gap
}

\begin{abstract}
Despite business models having been discussed thoroughly by academics there are still some epistemological and ontological issues that have yet to be resolved. Business models seem to have stalled at the technological era and have not fully engaged with the era of sustainability. The purpose of our paper is to add a new lens and richness to sustainable business model research by building on the need for more interdisciplinary approaches. This paper applies an eco-critical approach to analyse the 20 most often cited business model frameworks. We explore the conventional understanding of the business models based on the language applied and reflect on gaps in the current perspectives of sustainability. The analysis shows that existing business model frameworks exclude natural and social aspects of organisational environment from the discussion and tend to neglect the interrelationships between economic and not-economic actors as well as the intertemporal trade-offs. Based on the results of the analysis we propose a new sustainable business model framework named "Value Triangle", which explicitly includes as core elements society incorporating the natural environment and future generations and three types of co-created and co-delivered value: public, partner and customer. The Value Triangle together with the corresponding canvas is presented through a business case for sustainability represented by Italian company Loccioni. The results show that the proposed business model framework and canvas allow managers to understand, analyse and evaluate their business models along all three dimensions of sustainability - economic, social, and environmental simultaneously. Such an understanding helps drive the field towards making a meaningful contribution to solving the UN global challenges and sustainability agenda.
\end{abstract}

Key terms: business model canvas; business model framework; eco-criticism; sustainability; sustainable business model

\section{Introduction}

Teece (2010) claims that every firm working in a competitive market has a business model (BM) to create, deliver and capture value, whether explicitly recognised or not (Chesbrough, 2007). In essence, a BM represents the underlying logic of how the company is doing business, creates value for stakeholders and captures a share of value for itself. It is a concept that was explicitly recognised and developed during the years of the internet boom when firms and analysts came to realize that traditional ways of proposing and capturing value did not capitalize on new technologies and indeed, new technologies in themselves did not constitute an effective BM. They needed something different from traditional industrial economist based strategic concepts and something more aligned to practitioners, fast evolving markets, and the fuzziness that characterizes the network firm. This need was fulfilled by the BM concept, a way to articulate different perspectives on revenue flows, costs, relationships and alternative forms of business. With such interest and 
apparent application, the BM concept soon exceeded the bounds of e-commerce and established itself as a new managerial concept for the wider business community (Trimi and Berbegal-Mirabent, 2012).

The BM allows management to visualize, test and "fine-tune" strategic decisions, as well as guide them during the implementation process (Blank and Dorf, 2012; Hacklin and Wallnöfer, 2012; Seelos, 2010)) and thus improve organisational effectiveness (Tavlaki and Loukis, 2005). In the globalized business where competing on technology alone is increasingly difficult, innovation and product life cycle are shorter and accelerating, and the cost of R\&D is increasing, BMs have moved more to the fore. Indeed, Chesbrough (2007, p.12) highlights that: "Today, innovation must include business models, rather than just technology and R\&D. (...) A better business model often will beat a better idea or technology". While the theory of BMs is reasonably well developed, we believe it is still deficient (see Arend, 2013) especially regarding the eco-critical dimensions of business and value creation (Boons and Lüdeke-Freund, 2013; Schaltegger et al., 2016). This is critically important as the foundation of a modern and sustainable business (Hawken, 2010; Whiteman et al., 2013) which makes economic sense, while satisfying the ecological and social needs of the society. This forms the heart of our paper and leads us to question the appropriateness of existing business models as well as the need for a new perspective on sustainability within business model frameworks.

As society is calling for companies to respond to the 'planetary emergency' (Intergovernmental Panel on Climate Change, 2014) we need to reconsider two major issues relating to existing BM frameworks that form our main research questions.

Firstly, do business model frameworks provide a sufficiently holistic picture of business and its interdependent relationships with external environment including natural one?

Secondly, building on work by Kaplan and Jarzabkowski (2006) in terms of the conceptualization of a business model framework as "a space for debate and dialogue and a means to bring actors with very different viewpoints and interests together in a way that strategic choices are made" (p. 7), do we need to consider how the language used within the BM frameworks shapes management business decisions and actions (Spender, 2014) and how the exclusion of nature and broader society from the BMs' definitions may prevent a holistic understanding of the business environment (Shrivastava, 1994)?

We see these two research questions in the context of BM frameworks acting as social artefacts and shapers of our mental models about business and its relation to society and natural environment (see e.g. Rosner, 1995). As such, language determines the way we see the world and the more an artefact is known, the greater its impact is on a specific community. Therefore, according to the number of citations in Google Scholar, we can say that in the last decade BMs have generated more impact on global business community than most other management tools. For example, the paper 'Business models as models' written by Baden-Fuller and 
Morgan (2010) has been cited 825 times, as shows Google Scholar on February 9, 2017. In this view, BMs can be considered as a fundamental mechanism, which we can use to explore our two research questions and thus make a significant contribution to the field of Management.

While in the last decade, numerous calls have been made to "extend" the best-known BM frameworks to include sustainability they have failed. We believe this is partly attributable to the lack of comprehensive analyses in identifying the gaps in BM frameworks relating to the requirements of sustainability. The exceptions to this are works proposed by Upward and Jones (2016) and Joyce and Paquin (2016) although they limited their analysis to business model ontology proposed by Osterwalder and thus limit their contribution. The purpose of our paper is to add a new lens and richness to sustainable business model research building on the emphasized need for more interdisciplinary approaches (Broman et., 2017; Schaltegger et al., 2013; Schaltegger et al., 2016; Upward and Jones, 2016), and considering that within complex systems a little difference in understanding the context can dramatically change their final performance (Mitleton-Kelly, 2003). Such a new lens can represent an eco-critical approach that is used in the field of literature and explores the relationship between human beings and the physical environment as presented by written word (or images).

Our paper is structured as follows. We begin by providing an overview of the existing BM literature and establishing the theoretical and practical relevance of BMs before exploring emerging prominence of sustainability in $21^{\text {st }}$ Century business. This is followed by applying an eco-critical approach to analyse definitions and components of 20 most often cited BM frameworks. We explore the conventional understanding of the BM based on the language applied and reflect on gaps in the current perspectives of BMs in relation to sustainability. Considering the challenges to business in this age of disruption then the ecocritical perspective of BMs might lead to different and hopefully better understanding of how it is possible to achieve better results along economic, social and environmental dimensions at the same time. Based on the results of the analysis we propose a new BM framework named "Value Triangle" (VT), which explicitly includes as core elements society incorporating the natural environment and future generations together with three types of value that are co-created and co-delivered within a circular value system. The VT together with the corresponding canvas is presented and discussed with the support of a business case for sustainability represented by Italian company Loccioni.

\section{Literature Review}

\subsection{Conceptualization of the Business Model}

While the BM literature is still heterogeneous and fragmented, Zott et al. (2011) in a comprehensive review identified four common themes: that BM is a new unit of analysis that bridges traditional ones, such as firm, industry or network; it emphasizes a system-level perspective involving simultaneous consideration of the 
content and process of "doing business"; it emphasizes the activities performed by the focal firm and its customer, partners and suppliers; and explains value creation and value capturing.

Despite the increased interest in the BM concept by academics and managers, no common definition has yet been accepted, with most being somewhat fragmented in nature (see Massa et al., 2017). Considering that BM can be viewed as a social construct such a situation is not surprising (Berger and Luckmann, 1966). However, there are some similarities between different available definitions. The BM concept most often refers to value creation, delivery and capture. Among those definitions, one given by Teece (2010) is the most often cited: "The essence of a BM is in defining the manner by which the enterprise delivers value to customers, entices customers to pay for value, and converts those payments to profit. It thus reflects management's hypothesis about what customers want, how they want it, and how the enterprise can organize to best meet those needs, get paid for doing so, and make a profit." (p. 172). While we find this definition most useful, we also recognise that, as Nielsen (2012, p.27) claims, "the BM concept is perhaps the most discussed and at the same time the least understood of the newer business concepts" and as such, we need to better understand the concept itself.

Despite some substantive differences among definitions, the problem is that they converge towards some longstanding and well-known managerial concepts to which the BM concept relates but which at the same time differs (DaSilva and Trkman, 2014). In particular, although a BM captures key components of a business plan, a business plan deals with a number of additional operational issues that transcend the model. That is a BM is not a business strategy but includes a number of strategy elements; similarly, a BM relates to tactics but it is not tactics, and finally a BM represents business logic but not at the level of business processes. In our view a BM is a kernel of business strategy that includes the "Who, What, How, and Where?" (Onetti et al., 2012) of the business but not elements of the organisation model and competition (Magretta, 2002). Indeed, BM can be considered as a link between the firm's strategy and activities performed to execute it (Richardson, 2008). However, the nature of the business environment has moved on, yet the BMs seem to have stalled at the "new technology" era and impeded progress in sustainability. In this respect, we need to consider how the sustainability agenda has evolved and what prominence it now holds before evaluating the business models and their sustainability inclusiveness.

\subsection{Sustainability and the Business Agenda}

The environmental awareness of people and corporations has increased considerably in the past decades (Faganel and Trnavčevič, 2012; Fraj-andrés et al., 2009). Concerns over waste disposal, conservation of natural resources, and pollution caused directly or indirectly by the production or consumption cycles of both mature and growing economies, has affected purchasing behaviours, waste disposal and the manufacturing process (de Abreu et al., 2012; Jenkins and Yakovleva, 2006; Zhao et al., 2012). The industrial development of the past century brought worldwide improvement in the quality of life, but was achieved at a major cost to 
the natural environment: depletion of natural resources, pollution of air, water and soil, deforestation and climate change (Desrochers and Hoffbauer, 2009). Despite the significant improvements made by some companies regarding energy consumption and depletion of natural resources (Asif et al., 2013; Ciliberti et al., 2008; Evans et al., 2009, Zuo et al., 2012), these improvements have been insufficient to offset the rising resource use and environmental impacts associated with an increasing global population (UNEP, 2012; WWF, 2014). Moreover, these efficiency improvements may lead to increased product and service use, reflecting the concept of 'rebound effect' (Herring and Sorrell, 2009). At the same time, growing environmental and social consciousness of the public changed patterns of buying behaviour, inducing a significant shift in institutional thinking and the development of close relationships between politics, ecology and economy (Loureiro et al., 2012). Regulatory environmental constraints (see Commission of the European Communities, 2007) impose countries, industries and organisations long-term aspirations to develop innovations to lower carbon emissions and to implement energy efficient technologies and product; in effect, this encourages environmental sustainability and stimulates CSR. As a result, macro policies designed to force organisations to reduce emissions have proliferated (see McCormick, 2001). However, such policies tend to neglect the actual use of resources and the business processes associated with effective, efficient and responsible resource utilisation/reutilisation. While the concept of sustainability was developed from a theory of development equilibrium that includes simultaneous respect for economic growth, environmental protection and social equity (Rondinelli and Berry, 2000), the problem is further compounded by the persistent belief that competitive advantage and technological innovation are core to business survival (Chesbrough and Rosenbloom, 2002; Pisano, 2015). This has skewed the evolution of BMs out from social and environmental sustainability into more technology-supported innovation, which can generate new business opportunities, new markets and new revenue streams (Teece, 2010).

Considering the current state of things, we can say that, although issues of sustainability and environmental protection are interwoven in the modern conceptualization of business strategy, this is probably to the detriment of sustainable development as a whole. While institutionalising "sustainability" in a strategy goes some way to highlighting its importance, it does not deal with the inherent need to implement it in practice (Čadež and Czerny, 2010). For this, we believe it is not the strategy that is at the core of a sustainable company but the need to interweave sustainability into its business model, values and leadership, and from there into the company culture, as argued by Anderson (2009).

\subsection{Current Trends of Sustainable Business Models}

There are a range of perspectives on sustainable business models (Rauter et al., 2017). Somehow the situation is similar to the one that we could find in CSR area at the start of this century (Dahlsrud, 2008) with an abundance of definitions biased toward specific interests (e.g. B Corp, circular economy, green economy, social business). The literature tends to be divided into approaches built around the natural environment 
(Hawkin et al., 2005), social issues (Grassl, 2012) or big society. However, what is clear is a lack of integration across perspectives and a lack of larger academic interest in practical application. The exception to this trend can be seen to be Bocken et al. (2014) who provide a very helpful perspective of sustainable business model archetypes (Fig. 1).

\section{$=====$ INSERT FIGURE 1 ABOUT HERE $=====$}

We draw on Fig. 1 as an overview of the current trends in sustainable business models and offer the figure as a summary of different perspectives. The archetypes build on the business model categorisations of Boons and Lüdeke-Freund (2013) are classified as Technological, Social, and Organisational oriented business models. Technological archetypes have a dominant technical innovation component while social archetypes are dominated by social innovation and organisational archetypes are change driven. These various archetypes form the basis of where current trends in sustainable business models reside.

If this categorisation into archetypes can help us to make sense of the varieties of sustainable BMs and their stage of development, the principles for sustainable BMs proposed by Stubbs and Cocklin (2008) can help us to understand what are their key features:

1. A sustainable BM defines its purpose from economic, environmental and social aspects simultaneously.

2. A sustainable BM uses a triple bottom line approach in measuring performance.

3. A sustainable BM takes into account the needs of several stakeholders and does not favour shareholders.

4. A sustainable BM treats nature as a stakeholder and promotes environmental stewardship.

5. A sustainable BM encompasses the broader system as well as the narrow firm level perspective.

Having examined the role and importance of the environmental agenda, and the archetypes of sustainable business models, we can now turn our attention to the BM literature and examine to what extent BMs meet the current and emerging business environments. We apply an eco-critical approach to determine the extent to which current BM frameworks are meaningful.

\section{An Eco-Critical Comparison of the Twenty BM Frameworks - Methodology}

\subsection{Methodology}

Using a systematic literature review, 20 BM frameworks were selected for analysis. Figure 2 provides an 
overview of the methodology adopted and the approach to the systematic literature review and database development.

\section{$=====$ INSERT FIGURE 2 ABOUT HERE $=====$}

In the first step a broad foundation of sources containing the term "business model" or "business model framework" in the title, abstract, or keywords was compiled. Databases from EBSCO Business Source Premier, Thomson Reuters Web of Knowledge and Google Scholar were used. Three criteria were then applied to the selection process: the perceived quality of publication (based on the number of relevant citations in related literature), the coverage of the time span from 1998 (i.e. the year when first recognizable articles on BMs were published) to 2015, and an original definition of the BM relevant to organisations is given. Sources without a specific definition of the BM and its components, or with only marginally modified other's definitions, were excluded from the analysis (e.g. Bocken et al., 2014; Doz and Kosonen, 2010; McGrath, 2010; Seelos and Mair, 2007). Items written by the same author(s) were only considered once if they were based on the same BM conceptualization (e.g. Amit and Zott, Chesbrough). For example, the two most often cited authors Amit and Zott in their articles (e.g. Amit and Zott, 2001; Zott and Amit, 2007; 2008) kept unchanged the core part of the definition and BM components, so we considered only their highest cited article and included it in the final sample. At the end we selected the 20 most highly cited sources. The applied literature review follows a similar approach adopted by Coombes and Nicholson (2013) and Kitchenham and Brereton (2013) and allowed for a greater degree of validity and reliability in the results. However, we are very much aware that based on this technique, there may be some recently published papers, that in the future, could have an important impact on research and practice in the field but did not satisfy the "citation frequency" requirement (e.g. Boons and Lüdeke-Freund, 2013; Den Ouden, 2012). This is a clear limitation of our study. The overall framework used for analysis is constructed around Pateli and Giaglis $(2003 ; 2004)$ BM evaluative framework. These authors defined six sub-domains for e-BM analysis: definitions, components, taxonomies, representations, change methodologies and evaluation models. We applied the first two sub-domains that relate to definition of a BM ( the purpose, scope, and primary elements) and BM main components. The other four sub-domains are not relevant considering the scope of our analysis. While we recognise that their approach was developed around e-BMs we also recognise its adoptions by a number of authors (e.g. Al-Debei and Avison, 2010; Lambert, 2012) and the apparent usefulness of the framework.

\subsection{An Eco-Critical Approach}

In the past decade, concern for the planet's environmental future has moved into mainstream consciousness most markedly through the issues of global warming (or climate change as the more encompassing term), overconsumption of limited natural resources, and the toxic saturation of everything from industrialized food 
systems to children's toys. The growing awareness of the ecological context has registered in the social sciences including management through increasingly interdisciplinary approaches to understanding how something called "nature" is conceived and acted upon (Dryzek, 2005) and termed eco-criticism. Eco-criticism originates in environmental activism of the 1960s with texts such as Rachel Carson's Silent Spring (1962) catalysing that movement. The main idea of eco-criticism is that humans are inextricably woven into the social and natural fabric of the world that shaped them as well as shaping the world i.e. we can reconsider an organisation to be more than a social artefact and see it as a product of the planet's ecological systems. As such, eco-criticism takes an "earth-centred approach to literary studies" (Glotfelty and Fromm, 1996). Adopting this theory, eco-critics and theorists ask questions like: How humans relate to the natural world? How are the environmental issues, cultural issues concerning the environment, and attitudes towards nature presented and analysed? How individuals and organisations behave and react in relation to nature and ecological aspects? Despite the broad scope of inquiry and disparate levels of sophistication, all ecological criticism shares the fundamental premise that human culture is connected to the physical world, affecting it and affected by it. Most eco-critical work in literature shares a common motivation: "the troubling awareness that we have reached the age of environmental limits, a time when the consequences of human actions are damaging the planet's basic life support systems." (Glotfelty and Fromm, 1996). We believe this perspective to be worthy of consideration in the business domain. As such, an ecologically focussed criticism directs our attention to matters about which we need to be thinking i.e. the embedding of ecological issues within the essence of the business, and therefore its business model. This stimulates mindfulness towards ecological issues and encourages us to think differently and deeply about the relationship of humans to nature.

An Eco-critical perspective consists of a variety of techniques that are used to represent the dominant cultural conceptions of nature. In our case we applied an eco-critical appraisal approach (Stibbe, 2015) which allowed us to make a complex evaluation between the "potential" positive and negative language system and their practical ecological consequences according to a selected frame of reference or ecosophy i.e. ecological philosophy (see Stibbe, 2015), or in our case, a sustainable BM. We derived our ecosophy from various sustainable BM definitions (e.g. Bocken et al., 2014; Stubbs and Cocklin, 2008) and included: triple bottom line, long-term orientation, environmental limits, resilience, and systemic perspective. Therefore, we considered specific, concrete components of BMs and BM definitions as linguistic patterns that we compared with the concepts from the literature on sustainable BMs and then incorporated within the two sub-domains of Pateli and Giaglis $(2003 ; 2004)$ BM evaluative framework.

\section{An Eco-Critical Comparison of the Twenty BM Frameworks - Findings}

The first stage of our analysis of the 20 BMs is shown in Table 1. From this we derived 20 definitions and corresponding components of BMs. 


\subsection{Definitions}

A consensual definition of BMs has not yet emerged, reflecting the fact that the BM concept has been used in different disciplines and context (e.g. e-business, innovation, strategic management, and entrepreneurship) with different perspectives. According to categories identified by Bock and George (2011) we can classify the 20 BM definitions into six types: organisational design category (Al-Debei and Avison, 2010; Alt and Zimmermann, 2001; Dubosson-Torbay et al., 2002; Eriksson and Penker, 2000; Johnson et al., 2008; Morris et al., 2005; Seddon et al., 2004; Timmers, 1998), resource based view (Demil and Lecocq, 2010; Hamel, 2000; Hedman and Kalling, 2003; Shafer et al., 2005), narrative and sense-making category (CasadesusMasanell and Ricart, 2010; Magretta, 2002), transactive structures (Amit and Zott, 2001; Mahadevan, 2000), nature of innovation (Chesbrough and Rosenbloom, 2002), and opportunity driven (Bock and George, 2011; Osterwalder and Pigneur, 2010; Teece, 2010).

BM definitions span from the very detailed ones (e.g. Al-Debei and Avison, 2010; Alt and Zimmermann, 2001) to the very abstract ones like that given by Eriksson and Penker (2000). The oldest BM definition is the definition proposed by Timmers who defined a BM as "an architecture for the product, service and information flows, including a description of the various business actors and their roles; and a description of the potential benefits for the various business" $(1998$, p.4). The idea of considering BMs as a bridge connecting different actors that compose the business ecosystem is followed by other authors like Dubosson-Torbay et al. (2002), Mahadevan (2000), and Shafer et al. (2005). Other key elements of BM definitions relate to value creation, delivery and capture (e.g. Teece, 2010). However, from the eco-critical perspective there is not a word about proposing, creating or delivering value that goes beyond customers and shareholders as proposed by Schaltegger et al. (2016) or considering outcomes related to non-economic actors. All analysed definitions are explicitly or implicitly market and/or money earning oriented without consideration of the interplay between business, society and nature. For example, only Timmers (1998) uses word "benefit" that semantically transcend the limited understanding of benefit only as revenue or revenue stream. The BM definitions that we analysed define the borders of discussion in a way that excludes nature and corresponds to the contemporary struggle to understanding the place of business within the ecosystem (Neumayer, 2013). At the same time, they correspond to the discourse of neoclassical economics that is based on two implicit promises: (i) if someone buys something that they want, then their life is improved (i.e. purchase of a product is a short cut to wellbeing), and (ii) consumers can never be fully satisfied. According to Dryzek (2005) this type of discourse prevents development of either a reformist or radical environmental discourse that are necessary if we want to re-shape business in a more sustainable one. 


\subsection{Creating Value}

Modern discourse within the BM context is mostly framed around the value logic in terms of creating, delivering, and capturing value (e.g. Achtenhagen et al., 2013; Demil and Lecocq, 2010; Chesbrough and Rosenbloom, 2002; Johnson et al., 2008; Osterwalder and Pigneur, 2010; Shafer et al., 2005; Teece, 2010). This value concept is present in almost all of the analysed definitions. However, even if the kind of value is not clearly specified and is somehow left to the interpretation of the reader it can be understood that authors talk about economic and customer value only. For example, Amit and Zott (2001) say that value is to be created through the exploitation of business opportunities, while Dubosson-Torbay et al. (2002) as well as Teece (2010) say that firm creates and delivers value to customers in order to generate profitable and sustainable revenue streams. From the standpoint of the eco-critical perspective, creating value means to improve people's well-being by taking care of the natural environment and social community at the same time. According to Roos (2014) BMs must adhere to the principles of harmony, recycling, collaboration, moderation, and humanity in order to create economic, environmental, and social value. Except collaboration that relates to the concept of value network none of these principles is mentioned in the BM definitions analysed.

Relating to the question for whom the value is created, most of the definitions refer directly to the customers (e.g. Bock and George, 2011), or they are implicitly assumed (e.g. Osterwalder and Pigneur, 2010). There are only a few that mention other stakeholders (e.g. Casadesus-Masanell and Ricart, 2010; Seddon et al., 2004), business partners (Mahadevan, 2000) or various business actors (e.g. Timmers, 1998), a term ambiguous and limited. Therefore, the analysed BM frameworks clearly consider a limited group of stakeholders to be eligible for appropriation of value created by a firm. Value delivered beyond customers, business partners and the company are not considered. This fact does not correspond to the view of humans inextricably woven into the social and natural fabric of the world and is an area for BM adjustment.

\subsection{Components}

Many of the authors break frameworks into their "atomic" elements, also referred as "components", “functions", "attributes", "pillars", or "domains" (e.g. Alt and Zimmermann, 2001; Hamel, 2000; Johnson et al., 2008). The most consistently emphasized components (see Morris et al., 2005) concern: the value proposition; the customer segments (including type of customer, geographic area, and kind of relationships that firm establishes with them); the value network (including suppliers, partners and coalitions), the economic model (the revenue model or how the firm makes money), and the internal processes and competencies including supply chain management and networking (see Bock and George, 2011; Eriksson and Penker, 2000; Magretta, 2002; Hamel, 2000). What is lacking is a component specifically related to the environment or 
sustainability and taking a big picture, longer terms perspective that it "meets the needs of the present without compromising the ability of future generations to meet their own needs" (Brundtland Commission, 1987). From the eco-critical perspective awareness of the importance of time is crucial because of the inter-temporal trade-offs needed to safeguard intergenerational equity. The omission of "time" from BMs components (i.e. time is mentioned only by Al-Debei and Avison (2010), but not in terms of trade-off) contributes to shorttermism and the inability to consider long-term effects of business activities. Another critical issue can be referred to a lack of a true systemic perspective within the BM frameworks. In fact, no interplays among the BM components are identified or made explicit. This issue limits a comprehensive understanding of how the business operates and, as a result, the strategic learning processes needed to shift business actors to more sustainable modes of production and consumption cannot be fostered.

\section{Value Proposition}

The most influential component of a BM seems to be the value proposition (e.g. Demil and Lecocq, 2010; Teece, 2010) or its synonymous offerings (e.g. Amit and Zott, 2001; Hedman and Kalling, 2003; Morris et al., 2005). This finding is consistent with the findings of other similar studies and confirms Kaplan and Norton (2001) claim that the value proposition is 'the essence of strategy'. Value proposition is understood it terms of what a firm is committed to provide to its stakeholders and in the narrow term is defined as "a selected bundle of products and/or services that caters to the requirements of a specific customer segment" (Osterwalder and Pigneur, 2010, p. 22).

The prevailing definitions of value proposition can be considered as synonymous with a customer value proposition. On the other hand, in the eco-critical perspective, value proposition goes beyond customers, broadening its application to other stakeholders and considering ecological and social value together with the economic value (e.g. Boons and Lüdeke-Freund, 2013; Joyce and Paquin, 2016;). From the eco-critical perspective value proposition must add a positive social value and/or minimise negative environmental impacts beside delivering direct benefits for customers (Rauter et al., 2017). We can conclude that there is a need for a broader understanding of the value proposition that considers value delivered to a range of stakeholders beyond customers and shareholders.

\section{Customer Segments}

The next key component of the BM evaluation framework refers to the customer and more specifically to customer segments target (e.g. Dubosson-Torbay et al., 2002; Hamel, 2000; Magretta, 2002; Morris et al., 2005; Osterwalder and Pigneur, 2010). Morris et al. (2005) place an emphasis on the entrepreneurial view of the BM concept, arguing that "failure to adequately define the market is a key factor associated with venture failure" (p. 730), meaning that whether a firm is a start-up or established, the issue of the target customer is crucial and relates directly to the value proposition (Porter, 1996). However, it should be noted that customers are not confined to the output side of a BM, like passive recipients of the value proposition, but as proposed 
by Chesbrough (2006) they are actively involved in the value creation process. The idea of customers actively engaged in a multitude of interactions within value networks fits well with the eco-critical view that everything is interconnected and that the reality we perceive and act on is crafted in the process of mutual dialogue and not objectively given to us (see Sterling, 2003).

\section{The Value Network}

The discussion of key components in BM continues with the value network. Progress in information and communication technology (ICT) has significantly reduced transaction and coordination costs and thus uncoupled the value chain of many organisations and industries. Such cost reductions can be interpreted as fundamental drivers towards integrating partners and customers in inter-company processes and communication networks (Weinhardt et al., 2011) or so called business eco-systems (Leith, 2013). Value is no longer created by firms acting autonomously, but is co-created by joint action and formal and informal alliances (Beattie and Smith, 2013). Considering the fact that the BM concept was first developed within ecommerce, it is unsurprising that the value network is emphasized in almost all BM frameworks (e.g. Chesbrough and Rosenbloom, 2002; Dubosson-Torbay et al., 2002; Hamel, 2000; Hedman and Kalling, 2003; Timmers, 1998). This is clearly exposed by Zott and Amit (2008) who say that BMs represent a broader conceptualization of value co-creation that makes a shift from a value chain paradigm to a value network paradigm. For example, Hamel (2000) defines firm boundaries as a "bridge" between internal strategic resources and external value network composed of suppliers, partners, and coalitions.

From the eco-critical perspective, co-creation implies the idea of co-evolution and eco-system. Co-evolution is close to the ecological understanding of humankind's development according to which two (or more) species reciprocally affect each other's evolution. Relating to firms and their BMs the evolution happens within the business eco-systems composed of the business itself, customers, suppliers, competitors, technology, and society (including natural environment). Each business in the "eco-system" affects and is affected by the others, creating a constantly evolving relationship, as such, a sustainable BM requires the integration of a firm's capital, partners, suppliers, customers and other stakeholders into cooperative networks where they can co-evolve and positively influence each other. Indeed, Stubbs and Cucklin (2008) claim that an organisation must collaborate with key stakeholders in order to achieve sustainability for the system that the organisation is part of.

The BM frameworks analysed revealed two characteristics of the value network that are questionable from the eco-critical perspective. The first one is already mentioned above regarding the exclusion of society and natural environment from the groups of stakeholders considered within BM frameworks. The second is a focus on a linear material flow between partners, where the eco-critical perspective would consider a circular flow (e.g. the concept of circular economy) more appropriate, with an emphasis on service acquired rather than a tangible product per se (e.g. PSS - Product Service System). 


\section{Economic Factors}

The discussion of the value network as a BM component is closely interwoven with the economic factor of costs (e.g. Dubosson-Torbay, 2002; Magretta, 2002; Morris et al., 2005; Osterwalder and Pigneur, 2010; Teece, 2010), a common element discussed in the BM literature and linked to profit. In some BM frameworks, profit is explicitly mentioned as a component (e.g. Johnson et al., 2008); in others it is mentioned indirectly through cost and revenue. Some of them, besides mentioning revenue, also emphasize pricing as a component of the BM profitability (e.g. Hedman and Kalling, 2003).

From the eco-critical perspective this emphasis on economic cost and profit highlights the lack of connection between BMs and their impact on the natural environment, and the need to consider the economic components within a wider domain beside direct and indirect costs of resource provision. BMs apply a simplified conception of resource provision where the only cost considered is the money paid to the suppliers or internally to employees, while externalities that reflect full environmental and social costs are not considered (see Joyce and Paquin, 2016). Furthermore, current BMs overlook the negative impacts on the natural environment by confining understanding of value generation within a market exchange of goods and services for some economic value without considering by-products like waste and emissions. Such simplification is somehow contradictory to the complex interrelatedness between BMs and market actors emphasised within BM definitions. The result is a limited and distorted view of how business really impacts society and the natural environment. According to the holistic view of the eco-critical perspective, the value generated needs to include both long-term outcomes (internal and external consequences of organisation's business activities) and organisation's outputs (IR, 2013) - products (i.e. goods and services), waste and other by-products.

\section{The Internal Processes and Competencies}

Another important component of a BM are firm's capabilities or competencies (e.g. Amit and Zott, 2001; Casadesus-Masanell and Ricart, 2010; Dubosson-Torbay et al., 2002; Hamel, 2000; Magretta, 2002; Morris et al., 2005). Referring to the BM frameworks, capabilities and competencies are often used synonymously, e.g. Hamel (2000) uses core competencies as a common definition for a firm's skills and unique capabilities and competences. Close to the definition of firm's capabilities are firm's resources or key resources (Osterwalder and Pigneur, 2010) as exemplified by Applegate's (2001) definition of capabilities as "resources needed to turn concept into reality" (p.2). From the various definitions, we can deduce that capabilities and/or competencies are included as part of the firm's resources applied as an overall notion.

Resources mentioned in the BMs are people, technology, products, facilities, equipment, alliances, funding, brand or other assets that are required to deliver the value proposition to customers (e.g. Johnson et al., 2008). However, social (e.g. shared norms) and natural capital (e.g. clean air, biodiversity), which from the ecocritical perspective are equally important as economic or human capital, are not mentioned as resources. Yet, a proper consideration of natural capital is according to Hart (1995) a prerequisite for a firm's competitive 
advantage. For example, consideration of social capital has enabled development of modern social innovations (e.g. microcredits, Grameen Danone) and green solutions (Yunus et al., 2010). Future development of the BM concept closer to the sustainability paradigm will need to consider this fact.

Our analysis of the business models has profiled the current thinking and the key elements of the models most commonly discussed. Analysis shows that dominant BMs (i) exclude nature from their discussion as well other stakeholders outside customers, partners, suppliers and shareholders, (ii) include a limited understanding of costs and benefits, (iii) do not support inter-temporal trade-offs, (iv) emphasise a linear material flow and (v) lack a true systemic perspective. From this analysis we are clear that there is a dearth of knowledge relating to the sustainability and eco-agenda in BMs and the need to develop the understanding of co-operation, cocreation and values as vehicles to deliver a sustainability driven BM. Our findings suggest that BMs as commonly understood to treat the natural world as a given, mechanistic, and a resource base to be exploited, along with other business expenses (including human capital).

As such, we now seek to support and extend the needed characteristics of a sustainable BM as defined by Lüdeke-Freund et al. (2016), supporting societal progress, inclusion of social and environmental values beside the economic one, and a system level perspective that includes a multi-stakeholder view. In the next section we seek to redefine a BM concept and propose a framework, which we believe, adds more value to $21^{\text {st }}$ century business by enhancing human, social, and natural capital.

\section{The Value Triangle: Closing a Sustainable Gap}

\subsection{Theoretical foundation and elements of the VT}

Based on the results of our analysis of the 20 BM frameworks, we now propose a new BM framework termed "Value Triangle" (VT). The VT presumes firms co-create value within a business eco-system that includes society and natural environment (see Stubbs and Cocklin, 2008). More specifically the VT represents how a firm co-creates and co-delivers value with its stakeholders within a circular value system and capture some economic value from it. To display this, we propose a BM framework as presented in Fig. 3.

\section{===== INSERT FIGURE 3 ABOUT HERE =====}

This section explains the development of the framework using Richardson's (2008) three main components: value proposition, value co-creation and co-delivery system, and the value capture system and then highlights the contribution to the future of sustainable BM studies. 
1. The value proposition includes:

- Public value.

- Customer value.

- Partner value.

2. The value co-creation and co-delivery system includes:

- Society.

- Partners.

- Customers.

- Capital.

- Key operational activities.

- Products (i.e. goods \& services).

3. The value capture system includes:

- Revenue model.

- Cost structure.

There are four main features that differentiate the VT from most other BM frameworks. These are (i) an explicit orientation towards value co-creation for society at large, and not only for customers, business partners and in the last stage for organisation itself, (ii) comprehensive consideration of costs and benefits produced by organisation's business activities, (iii) a broad consideration of capital that includes anything that has a capacity to generate benefits including natural environment, (iv) BM components designed as triangles that replicate themselves in order to visually sustain a systemic relationships that exist between multiple actors working together within a business eco-system, and (v) a circular conception of value co-creation and codelivery.

Like other BM frameworks (e.g. Osterwalder and Pigneur, 2010), the VT puts the value proposition at the heart of the model. In the narrow term, the value proposition can be defined as an explicit promise made by a firm to its customers that will deliver a particular bundle of value creating benefits (Buttle, 2009). As this definition does not consider other stakeholders beyond customers and the value created in the partnerships with other actors of the business eco-system the VT applies a broader definition. The VT value proposition describes firm's commitment to co-create value for its stakeholders including society and natural environment in a way to fulfil their needs by solving sustainability challenges. Value represents the difference between benefits and costs that key stakeholders perceive in the short (i.e. outputs) and long term (i.e. outcomes). As per Voss et al. (2006) the benefits and costs must be considered in their economic, environmental and social aspect. In the view of sustainability, the difference between benefits and costs is considered as a change in the 
overall stock of capital. The VT draws on a stock of five types of capital: 1. financial, 2. manufactured, 3. human, 4. social or relationship, and 5. natural. The stock of capital is in constant flow as changes happen between and within the different types of capital (Porritt, 2007), however a sustainable BM maintains and when possible enhances the whole stock of capital, rather than depleting or degrading it. Comprehensive consideration of costs and benefit can help management to overcome the idea that harmful activities to nature or society can be compensated with positive impacts on financial or manufactured capital (Neumayer, 2013).

Value created by a firm is appropriated by different stakeholders. In the VT, value is appropriated by customers (i.e. customer value), by partners and suppliers (i.e. partner value), by social actors including environment and future generation (i.e. public value), and by the firm itself (i.e. captured value). The concept of public value proposed by Moore (1995) and further developed by Meynhardt (see Meynhardt, 2009, 2015; Meynhardt et al., 2014) represents a value contribution of a company to society and its functioning. In practice this means BM contributions to the solution of global challenges like the reduction of poverty, climate protection, the protection of biodiversity, creation of qualified jobs and broader competences (Grießhammer et al., 2007). The public value concept is similar to the well-known concept of shared value proposed by Porter and Kramer (2011), which is defined as economic value created and delivered "in a way that also creates value for society by addressing its needs and challenges" (p. 64). However, shared value has been criticized to see the company and economic value as primary (see Crane et al., 2014) while the sustainability movement puts humans and natural environment as primary. Shared value represents the inside-out view of how firms can align their commercial objectives with the societal one while the public value represents the outside-in vision of the sustainability as proposed by the Triple Bottom Line concept (Elkington, 1997). Public value is explicitly defined within VT (see the upper triangle in Fig. 3) and the framework orients management to consider how their firms create public value in the short and long term by collaborating with their partners and customers as well as with other social actors presented in the society (e.g. universities, public research labs, schools). Beside the public value two other types of value are critically important for organisation effectiveness. Customer value represents the customers' perception of value as a trade-off between the relevant benefits and sacrifices that they incur in a specific-use situation. On the other hand, partner value is defined as an economic value that is perceived by the firm's partners in form of return-on-investment, market growth, access to information, and knowledge development.

The VT considers value to be co-created and co-delivered within a circular value system (Tibbs, 2007). Within the circular value system, inputs (i.e. capital) are transformed into outputs (i.e. products, by-products, and waste). Basically the value co-creation starts on the top of the VT framework with society. Society has many roles to play beside the most important one of supporting life by eco-systems services. Society is a source of social and ecological challenges whose solution could represent an important market opportunity as well as is also a potential source of ideas and solutions for organisation's challenges (i.e. crowdsourcing). The assumption on which VT is based is that if a firm is "isolated" from the society it is not exposed to the best 
ideas and opportunities and as a result not as efficient as it could be economically speaking, but most importantly not responsible to the society at the level demanded by sustainable businesses (Hart and Sharma, 2004). The value co-creation process can develop along the left side (i.e. the resource side of the framework) or along the right side of the framework (i.e. the opportunity side of the framework). In the first case different actors within society assume the role of partners that supply firm with resources, knowledge, and capabilities. These external resources when properly integrated into firm improve its key activities and products' design making them more sustainable and in that way increasing the total value that at the end of the loop goes to society. In the latter case society proposes a problem for which firm in the first stage co-develops solution with other market and social actors and then designs around it other components of the BM in order to make the solution scalable on the broader level (Visser, 2011). Today the locus of value creation has moved from a firm to a network composed of different market and social actors involved in co-designing, co-creating and co-delivering firm's value proposition. Accordingly, we employ the notion of 'business eco-system' as a more generic conceptualisation of economic and social actors who create value within complex systems (Vargo and Lusch, 2011). As Leith (2013) argues, an eco-system is larger than a stakeholder system as it includes entities that are not generally viewed as stakeholder groups, such as 'anti-clients', activist groups and competitors. Within a value network, the roles of the company and the customer converge; they "are both collaborators and competitors, collaborators in co-creating value and competitors in extracting economic value" (Prahalad and Ramaswamy, 2004, p.11), but must importantly they increase the likelihood that socio-ecological effects of the product are assessed at an early point in time (Hallstedt et al., 2013).

\subsection{VT BM Canvas}

Based on the VT a VT BM canvas is built as its visual presentation to be used in practice. Humans like to process information in graphic form, and similarly to language, visual serves to express and clarify abstract concepts. In fact, strategy charts serve as a more comprehensive strategy communication tool than commonly used verbal and key word approaches. There are some important facts that need to be considered relating to the visual presentation of a BM: (i) visuals catch attention, (ii) visuals tap into a highly developed human cognitive skill; (iii) visuals are excellent in summarizing information; and (iv) visuals are "sticky" to the context. In that view the "linear flow" proposed by BM frameworks that are designed as rectangles and boxes (e.g. Osterwalder and Pigneur, 2010), leads users to think in a linear way without considering possible feedback loops that could exist among different actors. Neither the definition of the BMs, nor their visual presentation, recognises the cyclic nature of life that needs to be engendered for any shift to sustainability. On the other hand, we are part of the circle (i.e. the circle of life) as our ecosystem is interconnected and dependent on each other for survival. So our approach to human economies and ecologies must be addressed in a circular viewpoint not a linear one. For this reason, the VT is shaped in a way that its components are presented as triangles in order to effectively change the linear perception and reorient user to think in a circular way. For the same reason the society is put on the top as a source and the last recipient to emphasize the systemic 
interrelationship between business and society.

According to the definitions given above the VT BM canvas includes nine components, which are:

1. Society; it includes various stakeholders by whom firm establishes and maintains mutually beneficial relationships as well as natural environment with its eco-system services that represent a source of all human life and activities.

2. Value proposition; firm's statement to co-create and co-deliver value for its stakeholders including society and natural environment, by fulfilling their needs and solving their challenges.

3. Customers; the different group of people or organisations that the firm aims to reach and serve by its products and services as well as involved them in the co-creation of value.

4. Products; the bundle of goods and services that create values for customers by satisfying their needs and wants (i.e. customer value).

5. Key operational activities; key operational activities include inbound logistics (i.e. procurement and supply channels), R\&D, and operations as well as marketing and outbound logistics (i.e. distribution and communication channels). If these activities are carried out by the organisation or not, it depends on how much activities are externalized to partners through outsourcing.

6. Capital; Capital types used by the firm are: financial capital (e.g. cash used in transactions), manufactured capital (e.g. semi-products, infrastructure), intellectual capital (e.g. patents, tacit knowledge), human capital (e.g. labour, skills, motivation), social and relationship capital (e.g. shared norms, brand loyalty), and natural capital (e.g. clean air, biodiversity).

7. Partners; the network of suppliers and partners that makes the BM work. Organisation can establish different forms of partnership like joint ventures, networks, consortia, strategic alliances and trade associations (Barringer and Harrison, 2000).

8. Benefits; benefits are divided among benefits delivered to society and environment (i.e. public and partner value) and revenue sources by which firm captures some economic value for itself. The former are results of voluntary environmentally and socially oriented activities that goes beyond legal requirements or conventional business behaviour and through which a firm generates growth and development.

9. Costs; costs are divided between costs that represents the negative impact of firm's outcomes and outputs on society and environment and cost drivers that impact the financial aspects of firm's performance.

Sustainable business requires a change in the basic logic of value creation (Joyce and Paquin, 2016). This is hard to be achieved if management have no a proper sense-making tool that can help them to increase the likelihood of proper framing questions, gathering data, and conducting BM analyses for arriving at substantive sustainable solutions (Lozano, 2008). The VT framework has allowed us through an eco-critical perspective to propose a more holistic and sustainability driven approach to BMs. This approach not only highlights the eco-agenda as a core element for the development, innovation and operationalization of future business but also places in the business psyche the need to seek ways to promote human development by considering co- 
existence with the natural environment. The proposed framework offers an alternative view on BMs, a view that considers not only customers and the firm itself as key stakeholders within an ecosystem, but also other relevant business and social actors as for example municipalities, universities, research centres, social investors, and government agencies beside nature and future generations itself.

\section{Case Study - Findings and Discussion}

A single-case study of an Italian mid-size company, Loccioni, was selected to explore the implications of applying the VT and VT canvas in practice. Loccioni, which was founded in 1968 by Enrico Loccioni, represents a business case for sustainability according to the three requirements defined by Schaltegger et al. (2012). Firstly, Loccioni voluntarily pursues activities with the intention to contribute to the solution of societal or environmental problems. Secondly, Loccioni creates a positive business effect according to all financial and economic indicators. Thirdly, Loccioni creates economic success through its environmentally and socially oriented activities. We present the case of Loccioni as an illustrative case, designed to flesh out our arguments, rather than to be 'mined' to extract some theoretical concepts. The case study besides exemplifying the application of VT BM canvas in practice is also a tool for best practice sharing that is crucially needed for further development of the field, both in academia and in practice.

Loccioni is active in the measurement and control of industrial products and processes and characterised by a very high level of technological innovation and research. It has developed expertise in the sectors of energy, environment, industry, health, mobility, train, transport and aerospace, and works for some of the best-known international brands (Fiat, Siemens, Continental, Electrolux, Eni, Enel, Bosch). Turnover is approximately 60 million Euros per year. The main strength of the company is the high technological content of "creations" and a set of activities, which allows it to operate as a leader in small market niches developing customised solutions with little competition.

Loccioni believes that their good financial performance is due to the talent, ingenuity and creativity of the 400 employees (average age of 34 years, and 50\% of whom are graduates). The overall sales trend shown in Table 2, highlights the exceptional economic results of Loccioni over the last decade.

$=====$ INSERT TABLE 2 ABOUT HERE $=====$

\subsection{Loccioni's Business Model}

Fig. 4 shows the BM of Loccioni within VT BM canvas (VT canvas). Description of a BM can start from any 
component of the VT canvas, in the case of Loccioni it started from the society component. The number of different stakeholders and projects developed with them that are mentioned within the component society tell us how strong the firm's orientation to sustainability and social responsibility is.

\section{$====$ INSERT FIGURE 4 ABOUT HERE====}

\section{Society:}

In terms of society, the VT canvas helps to identify and present the connection that exists between the success of the company and its interest in the people and the territory, both the social and the natural. Loccioni defines itself as an "eco-centric" entity that exists at the centre of its specific environment. This stance is understood in both economic and geographic terms, and forms a platform which gives off signs of its stance and activities by creating hetero-centric waves of action, such as: attention to environmental issues, organising local conferences, developing strong links with neighbouring schools and universities, opening the company to the local population and developing satellite companies or new start-ups.

Loccioni invests in its employees and in the local territory support the personal and professional development of employees and their families, young people and local entrepreneurs. There are many initiatives and networks developed by Loccioni in order to realize the conviction of its founder who says "only through the people, the culture, the quality of life, and beauty can a company really generate wealth". These are shown in Table 3 below.

\section{===== INSERT TABLE 3 ABOUT HERE =====}

A special emphasis is put on the continual development process of individual growth, which runs along a broad time span. Employees are taken through a series of stimuli from pre-entry to post-entry. Such stimuli are provoked by intense paths of theory and practice. This innovative HR management goes through a process of three stages: Bluzone before potential employees enter the Group; Redzone during their stay in the Group; and Silverzone after officially leaving the Group. All this is done without anybody in the official position of HR manager. Here we can see one of the many self-supporting feedback loops that characterised Loccioni's $\mathrm{BM}$ and is linked to society. The educational and training activities within Bluzone build strong links between Loccioni and young pupils. Most of them also conduct a summer job in the company and even before entering university really want to work for Loccioni. The result is that these young people when involved in the business processes together with other actors from different networks (e.g. Nexus, NetPeople) built by 
Loccioni, bring passion and new knowledge to the company that enables it to generate more innovative products and solutions that gives it more visibility that attracts the best local and international talent. At the same time such a strong family feeling and concern for what happens to any individual involved with the company helps it to develop new products.

\section{Value proposition:}

From the VT BM the value proposition for Loccioni lies in two key market dimensions and one social/staff development dimension that is strongly linked to the territory and environmental issues. In terms of market: the firm "sells measurement", which is core to the market offering. Loccioni is able to sell data on-demand by gathering, transforming and holding it using basic principles of knowledge management. Secondly, as a system integrator of technological know-how, it develops cutting edge ideas and technology that help customers to solve their complex problems that other competitors are not able to solve.

The value proposition related to social-staff development is founded upon the Loccioni lifestyle concept. In this respect, to live the Loccioni lifestyle means plunging into a dynamic, open, stimulating and young reality that emphasises the strong bond between humanity and nature. The corporate culture is based on the principle of play, try and learn, and makes projects strongly innovation oriented.

\section{Customers:}

The customer base and customer relationships relate to the following:

- "Top Firms" that are leaders in their own business sectors; industrial companies, public companies, service companies, including Fiat, Siemens, Continental, Electrolux, Eni, Enel, Bosch, Mercedes, VW.

- SMEs strongly oriented to innovation and growth.

- Customers are chosen by Loccioni according to a) their potential for product co-creation and b) knowledge that can be learned from them and transferred to the company.

- Long-term relationship based on establishing trust from the first project onwards.

Most importantly Loccioni involves its customers in its own socially responsible projects. For example, Loccioni has involved its two long-term customers Enel and Whirlpool in the Leaf community project that is the first eco-sustainable community in Italy. Loccioni promotes its role as a hub connecting different technical competencies in a way to contribute to the territory and at the same time offering a living lab for its customers to test and verified own solutions. The "living labs" represent also a space for co-creation of new products and offerings.

\section{Products:}

The historical overview of Loccioni shows the incremental development of the Loccioni product range. The products are clearly divided into groups of customised technological solutions, which have evolved from 
individual technology modules to a sustainable and integrated architecture. What binds them into a common denominator is the competence of "measurement" and tailored made solutions. The company has embraced seven different product areas built around: Energy, Environment, Industry, Humancare, Mobility, Trains and transport, and finally Aerospace.

\section{Key operational activities:}

The key operational activities can be seen in Table 4 below. These are divided into internally oriented activities listed on the left side of the framework, and externally oriented activities listed on the right side of the framework.

\section{Capital:}

Loccioni has various forms of capital. In terms of social capital there is the wealth of experience and drive of Enrico Loccioni (Founder and president) and management team. Loccioni's management team consists of people who have entered as former students and progressed in the company to the top. This is part of the company philosophy to not employ directional figures from outside. Knowledge capital is captured and developed by dedicated and talented young professionals, through Summa srl, the internal service company, and the range of patents held by Loccioni. Physical capital is present in the form of the various production sites Moie di Maiolati (Italy) - General Impianti srl, Angeli di Rosora (Italy) - AEA srl, Columbia (SC - USA) - Loccioni USA Inc. and Shanghai (China) - Loccioni Rep. Office.

\section{Partners}

The company considers strategic suppliers as partners who are able to facilitate innovation and distinguish themselves through their drive for continuous improvement and new ideas. Suppliers are divided into international and local:

- International: the same philosophy that leads the research of customers, that is the ambition to work only with the top firms to increase its own bundle of competences, applies to suppliers.

- Local (not national): they are generally providers of services, primarily of the design and mechanical operations. The aim in this case is to support the economic growth of the territory. The project Nexus was created with an aim to nurture local suppliers' growth together with Loccioni, with a clause that Loccioni cannot represent more than $50 \%$ of their turnover. The same policy also applies to the company's spin offs where after 2 years they cannot depend on Locciani for more than $50 \%$ of their turnover. 
Loccioni delivers different benefits to local territory and environment. Social and environmental benefits include better trained and educated employees, development of local entrepreneurs, reduction of ecological footprint and development of a better sense of the local territory through socially responsible projects like Leaf community, Leaf garden, Flumen and Loccioni events. Leaf community, which includes Leaf House and Leaf School, is a living technological exercise based on a solar-thermal system that provides $26,500 \mathrm{kWh}$ per year of electricity, eliminating about 18 metric tons per year of CO2 emissions, and 10,200 kWh per year of heat energy, eliminating about 2.5 metric tons per year of $\mathrm{CO} 2$. On the other hand, Leaf garden is a nontechnological project that under the patronage of Loccini offers seasonal fruits and vegetables, herbs and natural flavours typical of the territory to guest and employees. Flumen is an "adoption" project of the Esino river, to secure and enhance $2 \mathrm{~km}$ of river area. Represents a collaboration between public and private in a joint action to protect water resources. While Loccioni events are thematic events open to public where the top professionals in the specific areas are invited to present their ideas and points of view.

In terms of creating an economic value Loccioni applies a revenue model characterised by the fact that the price level of its products is not directly comparable on the market. Loccioni is always looking for problems that need innovative and unique solutions and in that way it is never in a position to compete against a given price tag.

\section{Impacts:}

Loccioni is still unable to satisfy all its energy needs. Since it uses sun and water, it has peaks of consumption that cannot be satisfied and times when self-produced energy is too big to consumed within the company. As a result, $60 \%$ of electricity consumed by Loccioni group derives from the public electric grid and nonrenewable sources (see Bilancio Energetico 2015). Regarding the cost drivers, the main cost driver for Loccioni is represented by research investment as marginal costs of production are closed to zero.

\subsection{VT vs. traditional BMs}

Loccioni is a true activist company that uses sustainable BM to drive change and pursue its market leadership. Using a traditional BM canvas would not capture the richness of the societal contributions of Loccioni. Without inclusion of society and nature as a BM component it is difficult to expect that management would be able to go beyond its own mental models that are often shaped according to the neoclassical economic paradigm (Harrison, 2014; Rauter et al., 2017). The VT canvas on the other hand exposes the societal activities and highlights them for further development and recognises their importance in the overall operations of the business. In Loccioni, activities not strictly related to core business processes, namely activities related to networks development, internal transformation and external dialogue with social and economic actors within its business eco-system are really strategic. Traditional BMs that not include society as well as benefits and impacts produced by a firm would not fully describe the Loccioni's BM. For example, they would not describe 
all the activities developed with schools in order to attract the best students and the projects like Silverzone, or Nexus, which have no immediate impact on the business, but are among the most important ingredients of Loccioni's success. These projects can be considered as intertemporal trade-offs that are essential within sustainable business. The VT canvas provides a visual representation of a firm's BM that in essence follows a circular loop as advised by the principles of sustainable development. In that way, the VT canvas can be used as tool for analysing and communicating the current BM as in the case described above or for exploring the impact of possible innovations on the BM components including economic, social and environmental benefits and/or negative impacts.

The point is whether Loccioni is a business exception or an exceptional business. We are inclined to the second meaning, and we believe that all businesses will have to rethink their business model to pursue profit by regenerating the people and the planet. Our vision is to use business as a positive force so that all companies compete to be the best for the world, rather than in the world. The shift in the economic, productive and cultural paradigms is embodied by change from good products to good companies, in the belief that the best product of an entrepreneur is the company itself.

\section{Conclusion}

Our paper identified two key research questions to explore:

- Do business model frameworks provide a sufficiently holistic picture of business and its interdependent relationships with external environment?

- How the language used within the BMs frameworks shapes management business decisions and actions and specifically how the exclusion of nature and broader society from the BMs' definitions may prevent a holistic understanding of the business environment?

Adopting a systematic literature review to construct a conceptual framework of BM components, and then synthesis through the application to a case study context, we addressed both questions and found a number of key findings. While the findings have been discussed in the previous sections of this paper, we highlight the following as of major significance for development of the field.

Firstly, from our analysis we are clear that there is a dearth of knowledge relating to the sustainability and eco-agenda in BMs and as such a greater need to develop the understanding of co-operation, co-creation and values as vehicles to deliver a sustainability driven BM. We see this as particularly significant in the context of UN Global Challenges and the need to meet ethical consumer demands. As such, current business models do not provide a sufficiently holistic picture of business and interdependent relationships with the external environment. We appeal for more work to be done in this area. 
Secondly, language clearly plays a significant role in shaping management business decisions and actions and as such (Spender, 2014) the language used within BM definitions and development needs to evolve to align to the responsible management agenda and the need to protect depleted resources. In that view adopting an eco-critical perspective helps considering the whole BM structure and not opting for a bolt-on approach that could only perpetuate the problem rather than solve it. So, while we recognise that from time-to-time firms must alter their BMs due to changes in the market or social environment deplete existing BMs, competences and resources, we raises further questions towards how the BM is conceptualized and used. In particular the inclusion of categories or variables within the model itself.

While some advances have been made in consolidating and beginning to understand the state of the art in BM research, there is still a gap relating to the sustainability and eco-agenda, and the need to develop the understanding of co-operation, co-creation and values as vehicles to deliver a sustainability driven BM. BMs are commonly understood to treat the natural world as a given - mechanistic, a resource base to be exploited, or as another business expense (including human capital) to be minimized. Our research has shown that reconceptualising the $\mathrm{BM}$ around the value triangle allows for greater focus on elements that truly add value in a meaningful way. The application of the VT to the case has brought to the fore elements of the BM that would otherwise have been hidden and therefore not understood, yet core to the survival and growth of the business. We have shown therefore that there is a critical need to better understand the nature of the BM and evolve the BM field to meet the challenges and needs for the future, away from linear thinking and restricted views of "resource" to management recognise the cyclical nature of life that is necessary for sustainability.

We believe the VT gives us a solid foundation for rethinking and changing the firms' behaviour as a practical step forward in the process of developing a viable business eco-system according to the ecological paradigm. Components of the VT and its internal logic direct organisations to think about an opportunity to develop a competitive advantage by minimizing their environmental impact and contributing to a sustainable development of the society that they are part of (e.g. reducing the ecological footprint, or improving the welfare of key stakeholders).

\section{REFERENCES}

Achtenhagen, L., Melin, L., Naldi, L., 2013. Dynamics of business models - strategizing, critical capabilities and activities for sustained value creation. Long Rang. Plann. 46, 427-442.

Al-Debei, M.M., Avison, D., 2010. Developing a unified framework of the business model concept. Eur. J. Inform. Syst. 19, 359-376.

Alt, R., Zimmermann, H.-D., 2001. Business Models. EM-Electron. Mark. 11(1), 3-9.

Amit, R., Zott, C., 2001. Value Creation in e-Business. Strateg. Manage. J. 22, 493-520. 
Anderson, C., 2009. Free: The Future of a Radical Price. Hyperion, New York.

Applegate, L.M., 2001. Building Information Age Businesses for the 21st Century, in: Lowry, P.B., Owen Cherrington, J., Watson, R.R. (Eds.), E-Business Handbook. St. Lucie Press, Boca Raton, pp. 1-32.

Arend, R., 2013. The Business Model: Present and Future-Beyond a Skeuomorph. Strateg. Organ. 11(4), $390-402$.

Asif, M., Searcy, C., Zutshi, A., \& Fisscher, O. A., 2013. An integrated management systems approach to corporate social responsibility. J. Clean. Prod. 56, 7-17.

Baden-Fuller, C., Morgan, M.S., 2010. Business models as models. Long Rang. Plann. 43(2-3), 156-171.

Barringer, B.R., Harrison, J.S., 2000. Walking a tightrope: creating value through interorganizational relationships. J. Manage. 26, 367-403.

Beattie, V., Smith, S.J., 2013. Value creation and business models: Refocusing the intellectual capital debate. The Brit. Account. Rev. 45(4), 243-254.

Berger, P, Luckmann, T., 1966. The Social Construction of Reality-a Treatise in the Sociology of Knowledge. Penguin, London.

Blank, S.G., Dorf, B., 2012. The startup owner's manual: The step-by-step guide for building a great company. K \& S Ranch, Inc., Pescadero.

Bocken, N.M.P., Short, S.W., Rana, P., Evans, S., 2014. A literature and practice review to develop sustainable business model archetypes. J. Clean. Prod. 65(15), 42-56.

Boons, F., Lüdeke-Freund, F., 2013. Business models for sustainable innovation: state-of- the-art and steps towards a research agenda. J. Clean. Prod. 45, 9-19.

Bocken, N.M.P., Short, S.W., Rana, P., Evans, S., 2014. A literature and practice review to develop sustainable business model archetypes. J. Clean. Prod. 65. 42-56.

Broman, G., Robèrt, K-H., Collins, T.J., Basile, G., Baumgartner, R.J., Larsson, T., Huisingh, D., 2017. Science in support of systematic leadership towards sustainability. J. Clean. Prod. 140(1), 1-9.

Brundtland Commission, 1987. Our Common Future. Oxford University Press, New York.

Buttle, F., 2009. Customer Relationship Management. Elsevier, Burlington.

Casadesus-Masanell, R., Ricart, J.E., 2010. From strategy to business models and onto tactics. Long Rang. Plann. 43 (2-3), 195-215.

Chesbrough, H., 2006. Open Business Models: How to Thrive in the New Innovation Landscape. Harvard Business School Press, Boston.

Chesbrough, H., 2007. Business model innovation: It's not just about technology anymore. Strat. Lead. 35, $12-17$.

Chesbrough, H., Rosenbloom, R.S., 2002. The role of the business model in capturing value from innovation: Evidence from Xerox Corporation's Technology Spin-off Companies. Indust. and Corp. Chang. 11, $529-555$.

Ciliberti, F., Pontrandolfo, P., Scozzi, B., 2008. Investigating corporate social responsibility in supply chains: a SME perspective. J. Clean. Prod. 16(15), 1579-1588. 
Commission of the European Communities, 2007. Communication from the Commission to the Council, the European Parliament, the European Economic and Social Committee and the Committee of Regions. A European strategic energy technology plan. Towards a low carbon future. http://eurlex.europa.eu/LexUriServ/LexUriServ.do?uri=COM:2007:0723:FIN:EN:PDF (accessed 5.11.2013).

Coombes, P.H., Nicholson, J.D., 2013. Business models and their relationship with marketing: A systematic literature review. Ind. Mark. Manage. 42(5), 656-664.

Crane, A., Palazzo, G., Spence, L., Matten, D., 2014. Contesting the Value of "Creating Shared Value”. Calif. Manage. Rev. 56(2), 130-153.

Čadež, S., Czerny, A., 2010. Carbon management strategies in manufacturing companies. J. E. Eur. Manage. Stud. $15,348-360$.

Dahlrud, A., 2008. How corporate social responsibility is defined: an analysis of 37 definitions. Corp. Soc. Responsibility and Environ. Manage. 15(1), 1-13.

DaSilva, C.M., Trkman, P., 2014. Business model: what it is and what it is not. Long Rang. Plann. 47(6), 379389.

de Abreu, M.C.S., de Castro, F., de Assis Soares, F., \& da Silva Filho, J.C.L., (2012). A comparative understanding of corporate social responsibility of textile firms in Brazil and China. J. Clean. Prod. 20(1), 119-126.

Demil, B., Lecocq, X., 2010. Business model evolution: In search of dynamic consistency. Long Rang. Plann. 43(2), 227-246.

Den Ouden, E., 2012. Innovation Design: Creating Value for People, Organizations and Society. Springer, London.

Desrochers, P., Hoffbauer, C., 2009. The post war intellectual roots of the population bomb. Fairfield Osborn's 'Our Plundered Planet' and William Vogt's 'Road to Survival' in retrospect. Electron. J. Sust. Dev. 1(3), $37-61$.

Doz, Y.L., Kosonen, M., 2010. Embedding strategic agility: A leadership agenda for accelerating business model renewal. Long Rang. Plann. 43(2), 370-382.

Dryzek, J., 2005. The Politics of the Earth: Environmental Discourses, 2nd edition. Oxford University Press, Oxford.

Dubosson-Torbay, M., Osterwalder, A., Pigneur, Y., 2002. E-business model design, classification, and measurements. Thunderbird Int. Bus. Rev. 44, 5-23.

Elkington, J., 1997. Cannibals with Forks: The Triple Bottom Line of 21st Century Business. New Society Publishers, Stoney Creek.

Eriksson, H.-E., Penker, M. 2000. Business Modeling with UML: Business Patterns at Work. John Wiley \& Sons, New York.

Faganel, A., Trnavčevič, A. 2012. Sustainable natural and cultural heritage tourism in protected areas: case study. Annales, Series historia et sociologia 22(2), 589-600. 
Fraj-andrés, E., Martinez-Salinas, E., Matute-vallejo, J., 2009. A multidimensional approach to the influence of environmental marketing and orientation on the firm's organisational performance. J. Bus. Ethics. 88, 263-286.

Bock, A.J., George, G., 2011. The Business Model in Practice and Its Implications for Entrepreneurship Research. Entrepreneurship. Theory and Practice 35(1), 83-111.

Glotfelty, C., Fromm, H., (Eds.), 1996. The Ecocriticism Reader: Landmarks in Literary Ecology. The University of Georgia Press, Athens, Georgia and London.

Grassl, W., 2012. Business models of social enterprise: a design approach. J. Entrep. Perspect. 1(1), 37-60.

Grießhammer, R., Buchert, M., Gensch, C. O., et al., 2007. PROSA - Product sustainability assessment. Leitfaden. Öko-Institut (Ed.), http://www.prosa.org/fileadmin/user upload/pdf/leitfaden ENDVERSION.pdf (accessed August 2016).

Hacklin, F., Wallnöfer, M., 2012. The business model in the practice of strategic decision making: insights from a case study. Manage. Decis. 50(2), 166-188.

Hallstedt, S.I., Thompson, A.W., Lindahl, P., 2013. Key elements for implementing a strategic sustainability perspective in the product innovation process. J. Clean. Prod. 51, 277-288.

Hamel, G., 2000. Leading the Revolution: How to Thrive in Turbulent Times by Making Innovation a Way of Life. Harvard Business School Press, Boston.

Harrison, N.E., 2014. Sustainable Capitalism and the Pursuit of Well-being. Routledge, New York.

Hart, S.L., 1995. A natural-resource-based view of the firm. Acad. Manage. Rev. 20, 986-1014.

Hart, S.L., Sharma, S., 2004. Engaging fringe stakeholders for competitive imagination. Acad. Manage. Exec. 18(1), 7-18.

Hawken, P., 2010. The Ecology of Commerce: A Declaration of Sustainability, rev. ed. Harper Business, New York.

Hedman, J., Kalling, T., 2003. The business model concept: theoretical underpinnings and empirical illustrations. Eur. J. Inform. Syst. 12, 49-59.

Intergovernmental Panel on Climate Change, 2014. Climate Change 2014: Mitigation of Climate Change: Working Group III Contribution to the IPCC Fifth Assessment Report. Cambridge University Press, Cambridge.

Jenkins, H., Yakovleva, N., 2006. Corporate social responsibility in the mining industry: Exploring trends in social and environmental disclosure. J. Clean. Prod. 14(3), 271-284.

Johnson, M.W., Christensen, C.M., Kagermann, H., 2008. Reinventing your business model. Harvard Bus. Rev. 86, 50-59.

Joyce, A., Paquin, R.L., 2016. The triple layered business model canvas - A tool to design more sustainable business models. J. Clean. Prod. 135(1), 1474-1486.

Kaplan, R.S., Norton, D.P., 2001. The Strategy-Focused Organization: How Balanced Scorecard Companies Thrive in the New Business Environment. Harvard Business School Press, Boston.

Kaplan, S., Jarzabkowski, P., 2006. Using strategy tools in practice - How tools mediate strategizing and 
organizing. Advanced Institute of Management Research Paper N. 047.

Kitchenham, B., Brereton, P., 2013. A systematic review of systematic review process research in software engineering, Inf. and Softw. Technol. 55, 2049-207.

Lambert, S.C., 2012. Deconstructing Business Model Frameworks Using a Reference Model. Working Paper No. 4, Centre for Accounting, Governance and Sustainability Occasional Working Papers, University of South Australia, Adelaide.

Leith, J.M., 2013. What is an Enterprise Ecosystem? http://www.askyoda.net/enterprise-ecosystem/ (accessed April 2015).

Loureiro, S.M., Sardinha, I.M.D., Reijnders, L., 2012. The effect of corporate social responsibility on consumer satisfaction and perceived value: the case of the automobile industry sector in Portugal. $J$.

Clean. Prod. 37, 172-178.

Lozano, R., 2008. Envisioning sustainability three-dimensionally. J. Clean. Prod. 16, 1838-1846.

Lüdeke-Freund, F., Massa, L., Bocken, N., Brent, A., Musango, J., 2016. Business Models for Shared Value:

Main report. Network for Business Sustainability South-Africa, Cape town.

Magretta, J., 2002. Why business models matter. Harvard Bus. Rev. 80, 3-8.

Mahadevan, B., 2000. Business models for internet-based e-commerce: an anatomy. Calif. Manage. Rev. 42, $55-69$.

Massa, L., Tucci, C., Afuah, A., 2017. A Critical Assessment of Business Model Research. Acad. Manage. Ann. 11(1), 73-104.

McCormick, J., 2001. Environmental Policy in the European Union. Palgrave Macmillan, Basingstok.

McGrath, R.G., 2010. Business models: a discovery driven approach. Long Rang. Plann. 43(2), 247-261.

Meynhardt, T., 2009. Public Value Inside: What is Public Value Creation? Int. J. Pub. Adm. 32(3-4), 192219.

Meynhardt, T., 2015. Public Value: Turning a Conceptual Framework into a Scorecard, in: Bryson, J., Crosby, B., Bloomberg, L. (Eds.), Public Value and Public Administration. Georgetown University Press, Washington, pp. 147-169.

Meynhardt, T., Gomez, P., Schweizer, M., 2014. The Public Value Scorecard: What Makes an Organization Valuable to Society?. Performance, 6(1), 1-8.

Mitleton-Kelly, E., 2003. Complex systems and evolutionary perspectives on organisations: The application of complexity theory to organisations. Pergamon, Oxford.

Moore, M.H., 1995. Creating public value: strategic management in government. Harvard University Press, Boston.

Morris, M., Schindehutte, M., Allen, J. 2005. The entrepreneur's business model: toward a unified perspective. J. Bus. Res. 58, 726-735.

Neumayer, E., 2013. Weak versus strong sustainability: exploring the limits of two opposing paradigms, fourth ed. Edward Elgar, Cheltenham. 
Nielsen, C., 2012. A Brief History of the Business Model Concept, in: Nielesen, C., Lund, M. (Eds), Business Models: Networking, Innovating and Globalizing, Vol. 1, No. 2. BookBoon.com/ Ventus Publishing, Copenhagen, pp. 26-33.

Onetti, A., Zucchella, A., Jones, M., McDougall-Covin, P., 2012. Internationalization, innovation and entrepreneurship: business models for new technology-based firms. J. Manage. Gov. 16(3), 337-368.

Osterwalder, A., Pigneur, Y., 2010. Business Model Generation: A Handbook for Visionaries, Game Changers, and Challengers. Wiley, New Jersey.

Pateli, A.G., Giaglis, G.M., 2003. A Framework for Understanding and Analyzing e-Business Models. ecom.fov.unimb.si/proceedings.nsf/0/4c84233423603ad0c1256ea1002d1a29/\$FILE/25Pateli.pdf (accessed 30.09.2014).

Pateli, A.G., Giaglis, G.M., 2004. A research framework for analysing ebusiness models. Eur. J. Inform. Syst. $13,302-314$.

Pisano, G.P., 2015. You Need an Innovation Strategy. Harvard Bus. Rev. 93(6), 44-54.

Porritt, J., 2007. Capitalism As If The World Matters. Earthscan Limited, London.

Porter, M.E., 1996. What is strategy?. Harvard Bus. Rev. 74, 61-78.

Porter, M.E., Kramer, M.R., 2011. Creating shared value. Harvard Bus. Rev. 89, 62-77.

Prahalad, C.K., Ramaswamy, V., 2004. Co-Creation Experiences: the Next Practice in Value Creation. $J$. Interact. Mark. 18(3), 5-14.

Rauter, R., Jonker, J., Baumgartner, R.J., 2017. Going one's own way: drivers in developing business models for sustainability. J. Clean. Prod. 140, 144-154.

Richardson, J., 2008. The business model: an integrative framework for strategy execution. Strateg. Change 17(5-6), 133-144.

Rondinelli, D.A., Berry, M.A., 2000. Environmental citizenship in multinational corporations: social responsibility and sustainable development. Eur. Manage. J. 18, 70-84.

Roos, G., 2014. Business Model Innovation to Create and Capture Resource Value in Future Circular Material Chains. Resour. 3, 248-274.

Rosner, W.J., 1995. Mental models for sustainability. J. Clean. Prod. 3, 107-121.

Schaltegger, S., Beckmann, M., Hansen, E.G., 2013. Transdisciplinarity in Corporate Sustainability: Mapping the Field. Bus. Strateg. Env. 22, 219-229.

Schaltegger, S., Hansen, E.G., Lüdeke-Freund, F., 2016. Business Models for Sustainability: Origins. Present Research, and Future Avenues. Organ. Environ. 29(1), 3-10.

Schaltegger, S., Lüdeke-Freund, F., Hansen, E.G., 2012. Business cases for sustainability: the role of business model innovation for corporate sustainability. Int. J. Innov. Sust. Dev. 6(2), 95-119.

Seddon, P.B., Lewis, G.P., Freeman, P., Shanks, G., 2004. The case for viewing business models as abstractions of strategy. Commun. Assoc. Inform. Syst. (CAIS) 13, 427-442.

Seelos, C., 2010. Theorizing and Strategizing with models: Generative Models of Business Models. IESE Business School, Working Paper, 857, 1-29. 
Seelos, C., Mair, J., 2007. Profitable business models and market creation in the context of deep poverty: A strategic view. Acad. Manage. Perspect. 21(4), 49-63.

Shafer, S.M., Smith, H.J., Linder, J.C., 2005. The power of business models. Bus. Horizons 48, 199-207.

Shrivastava, P., 1994. Castrated environment: greening organizational studies. Org. Stud. 15, 705-726.

Spender, J.-C., 2014. Business Strategy. Managing Uncertainty, Opportunity, \& Enterprise. Oxford University Press, Oxford.

Sterling, S., 2003. Whole Systems Thinking as a Basis for Paradigm Change in Education: Explorations in the Context of Sustainability. (PhD thesis), Centre for Research in Education and the Environment, University of Bath. http://www.bath.ac.uk/cree/sterling/sterlingthesis.pdf (accessed 07.07.2013).

Stibbe, A., 2015. Ecolinguistics: Language, Ecology and the Stories We Live by. Routledge, London.

Stubbs, W., Cocklin, C., 2008. Conceptualizing a "sustainability business model”. Organ. Environ. 21(2), $103-127$.

Tavlaki, E., Loukis, E., 2005. Business Model: a prerequisite for success in the network economy, https://domino.fov.unimb.si/proceedings.nsf/0/9464c536b63d0f8fc1257014004a3b48/\$FILE/30Tavlaki.pdf (accessed 21.1.2015).

Teece, D.J., 2010. Business models, business strategy and innovation. Long Rang. Plann. 43, 172-194.

The International Integrated Reporting Council, 2013. The international 〈IR> report. http://www.theiirc.org/international-ir-framework/ (accessed 10.09.2013).

Tibbs, H., 2007. The Value Loop - A New Framework for Business Thinking, in: Marinova, D., Annandale, D., Phillimore, J. (Eds), The International Handbook on Environmental Technology Management. Edward Elgar, Cheltenham, pp. 534-553.

Timmers, P., 1998. Business models for electronic markets. Electron. Mark. 8, 3-8.

Trimi, S., Berbegal-Mirabent, J., 2012. Business model innovation in entrepreneurship. Int. Entrep. Manage. J. 8(4), 449-465.

Upward, A., Jones, P., 2016. An Ontology for Strongly Sustainable Business Models Defining an Enterprise Framework Compatible With Natural and Social Science. Organ. Environ. 29(1), 97-123.

Vargo, S.L., Lusch, R.F., 2011. It's All B2B...and Beyond: Toward A Systems Perspective Of The Market. Ind. Market. Manage. 40 (2), 181-187.

Visser, W., 2011. The age of responsibility: CSR 2.0 and the new DNA of business. John Wiley \& Sons, Chichester.

Voss, J-P., Bauknecht, D., Kemp, R., 2006. Reflexive Governance for Sustainable Development. Edward Elgar, Cheltenham UK.

Weinhardt, C., Blau, B., Conte, T., Filipova-Neumann, L., Meinl, T., Michalk, W., 2011. Business Aspects of Web Services. Springer, Berlin.

Whiteman, G.M., Walker, B., Perego, P.M., 2013. Planetary boundaries: ecological foundations for corporate sustainability. J. Manage. Stud. 50, 307-336. 
WWF, 2014. Living Planet Report 2014. http://assets.worldwildlife.org/publications/723/files/original/WWF$\underline{\text { LPR2014-low_res.pdf?1413912230\&_ga=1.18880888.1396751849.1487165243 }} \quad$ (accessed 06.02.2016).

Yunus, M., Moingeon, B., Lehmann-Ortega, L., 2010. Building Social Business Models: Lessons from the Grameen Experience. Long Rang. Plann. 43(2), 308-325.

Zhao, Z.Y., Zhao, X.J., Davidson, K., Zuo, J., 2012. A corporate social responsibility indicator system for construction enterprises. J. Clean. Prod. 29, 277-289.

Zott, C., Amit, R., 2007. Business model design and the performance of entrepreneurial firms. Organ. Sci. 18, 181-199.

Zott, C., Amit, R., 2008. The fit between product market strategy and business model: Implications for firm performance. Strategic Manage. J. 29, 1-26.

Zott, C., Amit, R., Massa, L., 2011. The business model: recent developments and future research. J. Manage. 37, 1019-1042.

Zuo, J., Zillante, G., Wilson, L., Davidson, K., \& Pullen, S. (2012). Sustainability policy of construction contractors: A review. Renew. and Sustain. Energy Rev. 16(6), 3910-3916. 
Figure 1: The sustainable business model archetypes (based on Bocken et al., 2014)

\begin{tabular}{|c|c|c|c|c|c|c|c|c|}
\hline$\hat{\bar{z}}$ & \multicolumn{3}{|c|}{ Technological } & \multicolumn{3}{|c|}{ Social } & \multicolumn{2}{|c|}{ Organisational } \\
\hline 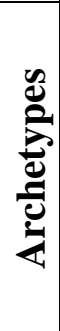 & $\begin{array}{l}\text { Maximise } \\
\text { material } \\
\text { and } \\
\text { energy } \\
\text { efficiency }\end{array}$ & $\begin{array}{l}\text { Create } \\
\text { value } \\
\text { from } \\
\text { waste }\end{array}$ & $\begin{array}{c}\text { Substitute } \\
\text { with } \\
\text { renewables } \\
\text { and natural } \\
\text { processes }\end{array}$ & $\begin{array}{c}\text { Deliver } \\
\text { functional } \\
\text { ity rather } \\
\text { than } \\
\text { ownershi } \\
\text { p }\end{array}$ & $\begin{array}{c}\text { Adopt a } \\
\text { stewardshi } \\
\text { p role }\end{array}$ & $\begin{array}{c}\text { Encourag } \\
\mathrm{e} \\
\text { sufficienc } \\
\mathrm{y}\end{array}$ & $\begin{array}{l}\text { Repurpose } \\
\text { for } \\
\text { society/ } \\
\text { environme } \\
\text { nt }\end{array}$ & $\begin{array}{l}\text { Develop } \\
\text { scale up } \\
\text { solutions }\end{array}$ \\
\hline
\end{tabular}

Figure 2: Research methodology

\section{Broad research database formation}

Using a systematic literature review by searching terms: Business model, Business model framework

In: Title, Key words, and/or Abstract

For period: 1998 - 2015

Narrowing research database

Selecting relevant sources with own BM and BM components definition

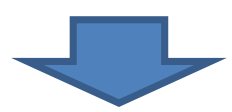

\section{Ranking selected sources}

Sources ranked according to their number of citations

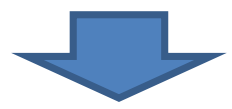

\section{Final research database formation}

Database containing the list of 20 most highly cited sources
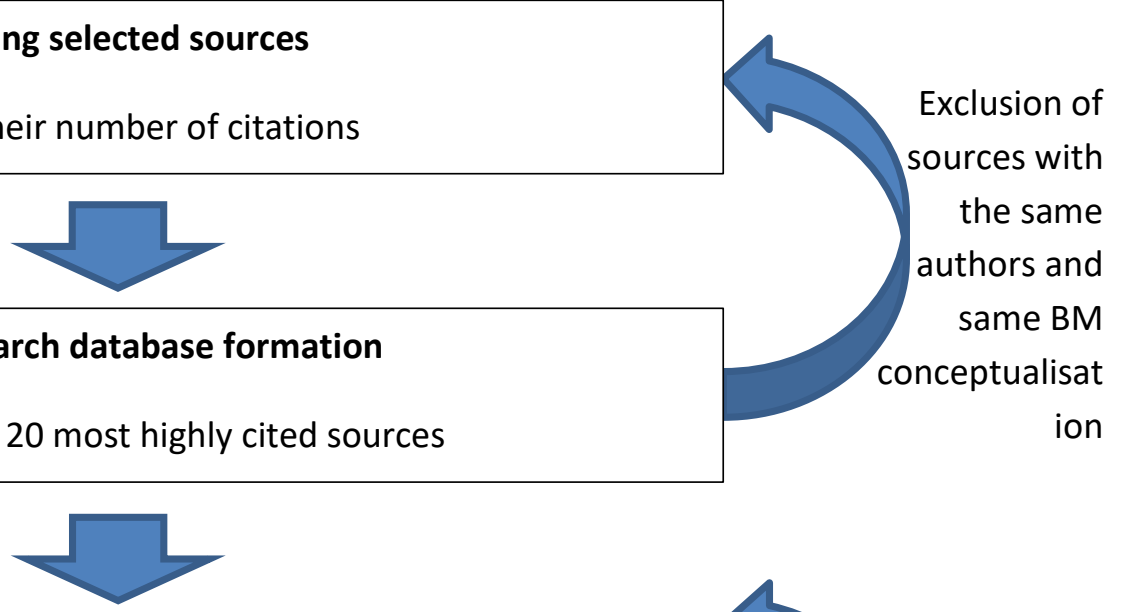

\section{Analysing selected sources from the eco-critical perspective}

Comparing BM definitions and BM components definitions with the ecosophy based on sustainable BM: triple bottom line, long-term orientation, environmental limits, resilience, systemic perspective 
Figure 3: The Value Triangle

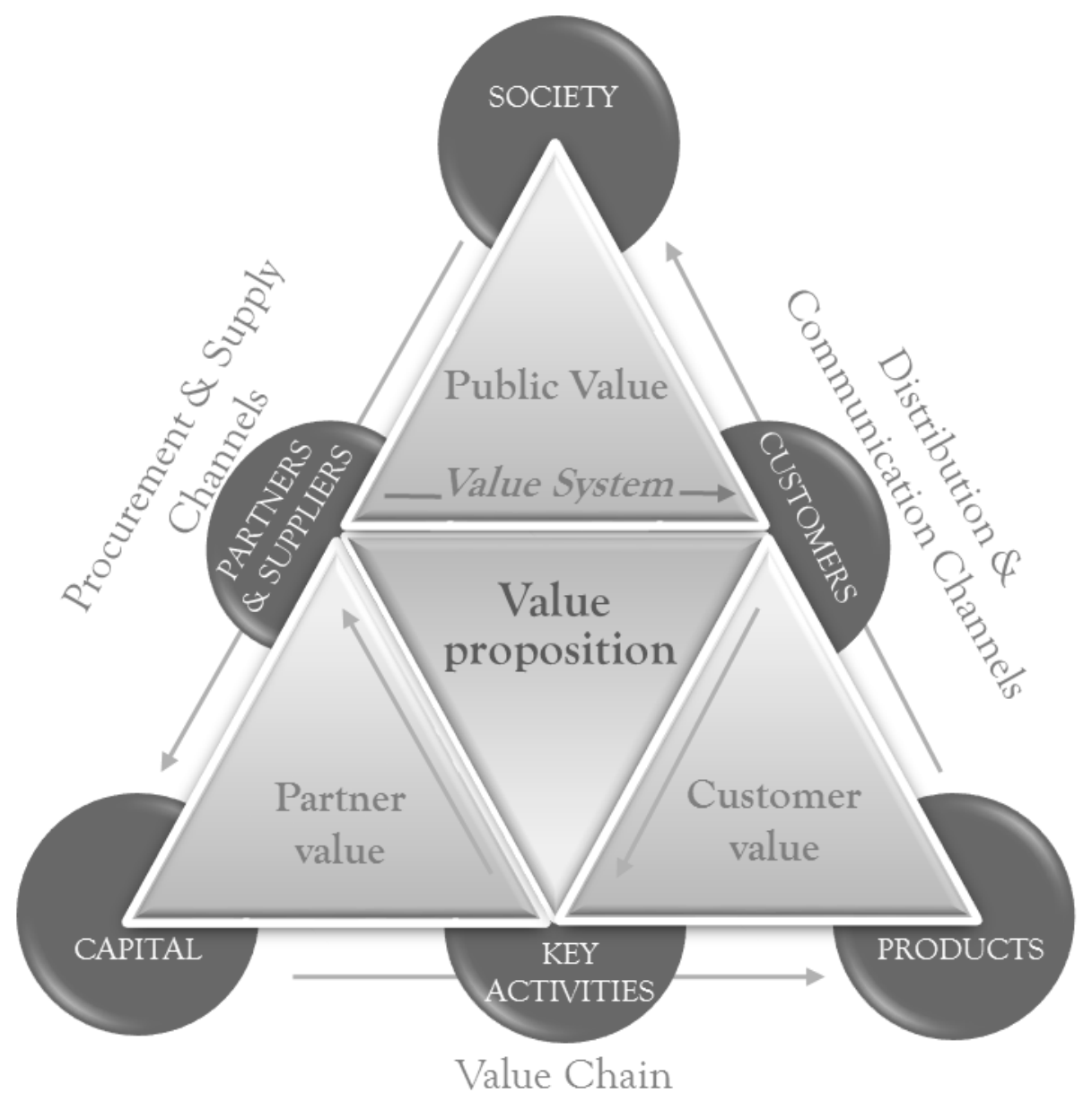




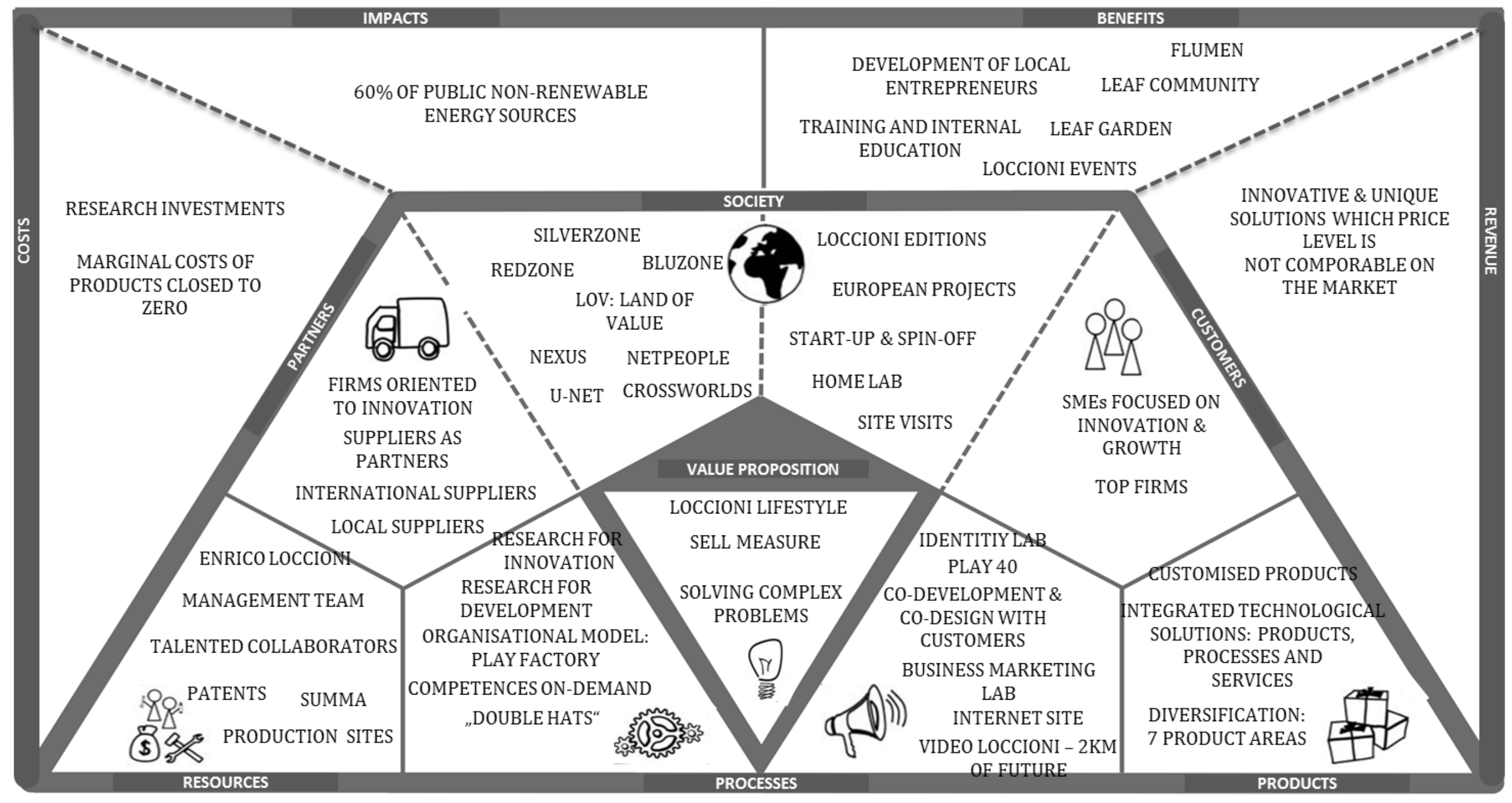


Table 1: Twenty BMs analysed

\begin{tabular}{|c|c|c|c|c|c|}
\hline Author & Title & Year & $\begin{array}{c}\text { Journal/ } \\
\text { Book title }\end{array}$ & Business Model Definition & Business Model Components \\
\hline $\begin{array}{l}\text { AL-DEBEI, M.M. } \\
\text { and AVISON, D. }\end{array}$ & $\begin{array}{l}\text { Developing a } \\
\text { unified framework } \\
\text { of the business } \\
\text { model concept }\end{array}$ & 2010 & $\begin{array}{l}\text { European Journal } \\
\text { of Information } \\
\text { Systems }\end{array}$ & $\begin{array}{l}\text { The BM is an abstract representation of an } \\
\text { organisation, be it conceptual, textual, and/or } \\
\text { graphical, of all core interrelated } \\
\text { architectural, co-operational, and financial } \\
\text { arrangements designed and developed by an } \\
\text { organisation presently and in the future, as } \\
\text { well all core products and/or services the } \\
\text { organisation offers, or will offer, based on } \\
\text { these arrangements that are needed to } \\
\text { achieve its strategic goals and objectives. }\end{array}$ & $\begin{array}{l}\text { Value proposition, Value architecture, Value } \\
\text { network, Value finance }\end{array}$ \\
\hline $\begin{array}{l}\text { ALT, R. } \\
\text { and } \\
\text { ZIMMERMAN, H.- } \\
\text { D. }\end{array}$ & Business Models & 2001 & $\begin{array}{l}\text { EM-Electronic } \\
\text { Markets }\end{array}$ & $\begin{array}{l}\text { The BM is composed of six generic } \\
\text { elements: Mission (Goals, Vision, Value } \\
\text { Proposition), Structure (Actors and } \\
\text { governance, Focus), Processes (customer } \\
\text { orientation, coordination mechanism), } \\
\text { Revenues (source of revenues, business } \\
\text { logic), Legal issues, and Technology (both } \\
\text { an enabler and constraint for IT-based } \\
\text { business models). }\end{array}$ & $\begin{array}{l}\text { Mission (goals, vision, value proposition), } \\
\text { Structure (actors and governance, focus), } \\
\text { Processes (customer orientation, coordination } \\
\text { mechanism), Revenues (source of revenues, } \\
\text { business logic), Legal issues, Technology }\end{array}$ \\
\hline $\begin{array}{l}\text { AMIT, R. } \\
\text { and } \\
\text { ZOTT, C. }\end{array}$ & $\begin{array}{l}\text { Value Creation in } \\
\text { E-Business }\end{array}$ & 2001 & $\begin{array}{l}\text { Strategic } \\
\text { Management } \\
\text { Journal }\end{array}$ & $\begin{array}{l}\text { A BM depicts the content, structure, and } \\
\text { governance of transactions designed so as to } \\
\text { create value through the exploitation of } \\
\text { business opportunities. }\end{array}$ & $\begin{array}{l}\text { Resources/Assets, Capabilities/Competences, } \\
\text { Information flows, Output (offerings), Product/ } \\
\text { service flows, Business opportunities, Value } \\
\text { creation, Transaction content, Transaction } \\
\text { governance, Transaction structure }\end{array}$ \\
\hline $\begin{array}{l}\text { BOCK, A.J. and } \\
\text { GEORGE, G. }\end{array}$ & $\begin{array}{l}\text { The Business } \\
\text { Model in Practice } \\
\text { and Its Implications } \\
\text { for } \\
\text { Entrepreneurship } \\
\text { Research }\end{array}$ & 2011 & $\begin{array}{l}\text { Entrepreneurship } \\
\text { Theory and } \\
\text { Practice }\end{array}$ & $\begin{array}{l}\text { The BM is the design } \\
\text { of organisational structures to enact a } \\
\text { commercial opportunity. }\end{array}$ & $\begin{array}{l}\text { Resource structure, Transactive structure, Value } \\
\text { structure }\end{array}$ \\
\hline $\begin{array}{l}\text { CASADESUS- } \\
\text { MASANELL, R. } \\
\text { and RICART, J.E. }\end{array}$ & $\begin{array}{l}\text { From Strategy to } \\
\text { Business Models } \\
\text { and onto Tactics }\end{array}$ & 2010 & $\begin{array}{l}\text { Long Range } \\
\text { Planning }\end{array}$ & $\begin{array}{l}\text { BM refers to the logic of the firm, the way it } \\
\text { operates and how it creates value for its } \\
\text { stakeholders. A firm's BM is a reflection of } \\
\text { its realized strategy. }\end{array}$ & $\begin{array}{l}\text { The concrete choices made by management about } \\
\text { how the organization must operate (policy, asset, } \\
\text { and governance choices), The consequences of } \\
\text { these choices }\end{array}$ \\
\hline
\end{tabular}




\begin{tabular}{|c|c|c|c|c|c|}
\hline $\begin{array}{l}\text { CHESBROUGH, } \\
\text { H.W. and } \\
\text { ROSENBLOOM, } \\
\text { R.S. }\end{array}$ & $\begin{array}{l}\text { The role of the } \\
\text { business model in } \\
\text { Capturing value } \\
\text { from innovation: } \\
\text { evidence } \\
\text { From Xerox } \\
\text { Corporation's } \\
\text { technology } \\
\text { spin-off companies }\end{array}$ & 2002 & $\begin{array}{l}\text { Industrial and } \\
\text { Corporate } \\
\text { Change }\end{array}$ & $\begin{array}{l}\text { The BM provides a coherent framework that } \\
\text { takes technological characteristics and } \\
\text { potentials as inputs, and converts them } \\
\text { through customers and markets into } \\
\text { economic outputs. The BM is thus conceived } \\
\text { as a focusing device that mediates between } \\
\text { technology development and economic value } \\
\text { creation. }\end{array}$ & $\begin{array}{l}\text { Value proposition, Market segment, Structure of } \\
\text { the value chain, Cost structure and profit potential, } \\
\text { Position of the firm within the value network }\end{array}$ \\
\hline $\begin{array}{l}\text { DEMIL, B. and } \\
\text { LECOCQ, } X \text {. }\end{array}$ & $\begin{array}{l}\text { Business Model } \\
\text { Evolution: In } \\
\text { Search of Dynamic } \\
\text { Consistency }\end{array}$ & 2010 & $\begin{array}{l}\text { Long Range } \\
\text { Planning }\end{array}$ & $\begin{array}{l}\text { Generally speaking, the concept refers to the } \\
\text { description of the articulation between } \\
\text { different BM components or "building } \\
\text { blocks" (resources and competences, } \\
\text { organization, value propositions) to produce } \\
\text { a proposition that can generate value for } \\
\text { consumers and thus for the organization. }\end{array}$ & $\begin{array}{l}\text { Resources and competences, Organizational } \\
\text { structure, Value propositions }\end{array}$ \\
\hline $\begin{array}{l}\text { DUBOSSON- } \\
\text { TORBAY ET AL. }\end{array}$ & $\begin{array}{l}\text { E-Business Model } \\
\text { Design, } \\
\text { Classification, and } \\
\text { Measurements. }\end{array}$ & 2002 & $\begin{array}{l}\text { Thunderbird } \\
\text { International } \\
\text { Business Review }\end{array}$ & $\begin{array}{l}\text { A BM is nothing else than the architecture of } \\
\text { a firm and its network of partners for } \\
\text { creating, marketing and delivering value and } \\
\text { relationship capital to one or several } \\
\text { segments of customers in order to generate } \\
\text { profitable and sustainable revenue streams. }\end{array}$ & $\begin{array}{l}\text { Product innovation (value proposition, target, } \\
\text { capabilities), Customer relationship (getting a feel } \\
\text { for the customer, serving the customer, branding), } \\
\text { Infrastructure management (resources/assets, } \\
\text { activity/processes, partner network), Financial } \\
\text { aspects (revenue, cost profit). }\end{array}$ \\
\hline $\begin{array}{l}\text { ERIKSSON, H.-E. } \\
\text { and PENKER, M. }\end{array}$ & $\begin{array}{l}\text { Business Modeling } \\
\text { with UML: } \\
\text { Business Patterns at } \\
\text { Work. }\end{array}$ & 2000 & Book & $\begin{array}{l}\text { A business model is a simplified view of a } \\
\text { business i.e. is an abstraction of how a } \\
\text { business functions. }\end{array}$ & Resources, Processes, Goals, Rules \\
\hline HAMEL, G. & $\begin{array}{l}\text { Leading the } \\
\text { Revolution }\end{array}$ & 2000 & Book & $\begin{array}{l}\text { The BM is a business concept that has been } \\
\text { put into practice. }\end{array}$ & $\begin{array}{l}\text { Customer interface, Core strategy, Strategic } \\
\text { resources, Value network, Bridging components }\end{array}$ \\
\hline $\begin{array}{l}\text { HEDMAN, J. and } \\
\text { KALLING, T. }\end{array}$ & $\begin{array}{l}\text { The business model } \\
\text { concept: theoretical } \\
\text { underpinnings and } \\
\text { empirical } \\
\text { illustrations }\end{array}$ & 2003 & $\begin{array}{l}\text { European Journal } \\
\text { of Information } \\
\text { Systems }\end{array}$ & $\begin{array}{l}\text { The BM is a strategy model which unites the } \\
\text { finer aspects of strategy, i.e. resource-bases, } \\
\text { activities, structure, products, and external } \\
\text { factors. }\end{array}$ & $\begin{array}{l}\text { Customer, Competition, Offering, Activities and } \\
\text { organisation, Resources, Suppliers, Management }\end{array}$ \\
\hline $\begin{array}{l}\text { JOHNSON, M.W., } \\
\text { CHRISTENSEN, } \\
\text { C.M. and } \\
\text { KAGERMANN, H. }\end{array}$ & $\begin{array}{l}\text { Reinventing Your } \\
\text { Business Model }\end{array}$ & 2008 & $\begin{array}{l}\text { Harvard Business } \\
\text { Review }\end{array}$ & $\begin{array}{l}\text { A BM consists of four interlocking } \\
\text { elements (i.e. customer value proposition, } \\
\text { profit formula, key resources, and key } \\
\text { processes) that, taken together, create and } \\
\text { deliver value. }\end{array}$ & $\begin{array}{l}\text { Customer value proposition, Profit formula, Key } \\
\text { resources, Key processes. }\end{array}$ \\
\hline
\end{tabular}




\begin{tabular}{|c|c|c|c|c|c|}
\hline MAGRETTA, J. & $\begin{array}{l}\text { Why Business } \\
\text { Models Matter }\end{array}$ & 2002 & $\begin{array}{l}\text { Harvard Business } \\
\text { Review }\end{array}$ & $\begin{array}{l}\text { The BM as a system is a description of how } \\
\text { the pieces of a business fit together. } \\
\text { However, it does not deal with competition. }\end{array}$ & $\begin{array}{l}\text { Value proposition, Customer (target market, } \\
\text { scope), Cost, Economics, Profit }\end{array}$ \\
\hline MAHADEVAN, B. & $\begin{array}{l}\text { Business Models } \\
\text { for Internet-Based } \\
\text { E-Commerce: An } \\
\text { Anatomy }\end{array}$ & 2000 & $\begin{array}{l}\text { California } \\
\text { Management } \\
\text { Review }\end{array}$ & $\begin{array}{l}\text { A BM is a unique blend of three streams that } \\
\text { are critical to the business. These include the } \\
\text { value stream for the business partners and the } \\
\text { buyers, the revenue stream, and the logistical } \\
\text { stream. }\end{array}$ & $\begin{array}{l}\text { Value network (Suppliers/partners), Value } \\
\text { proposition, Revenue/Pricing, Product/service } \\
\text { flows }\end{array}$ \\
\hline $\begin{array}{l}\text { MORRIS, M., } \\
\text { SCHINDE-HUTTE, } \\
\text { M. and } \\
\text { ALLEN, J. }\end{array}$ & $\begin{array}{l}\text { The entrepreneur's } \\
\text { business model: } \\
\text { toward a unified } \\
\text { perspective }\end{array}$ & 2005 & $\begin{array}{l}\text { Journal of } \\
\text { Business Research }\end{array}$ & $\begin{array}{l}\text { A business model is a concise representation } \\
\text { of how an interrelated set of decision } \\
\text { variables in the areas of venture strategy, } \\
\text { architecture, and economics are addressed to } \\
\text { create sustained competitive advantage in } \\
\text { defined markets. }\end{array}$ & $\begin{array}{l}\text { Value network (Suppliers/partners), Strategy, } \\
\text { Capabilities/Competences, Output (offerings), } \\
\text { Financial aspects, Create value, Economics, } \\
\text { Competitors }\end{array}$ \\
\hline $\begin{array}{l}\text { OSTERWALDER, } \\
\text { A. and PIGNEUR, } \\
\text { Y. }\end{array}$ & $\begin{array}{l}\text { Business Model } \\
\text { Generation: A } \\
\text { Handbook for } \\
\text { Visionaries, Game } \\
\text { Changers, and } \\
\text { Challengers } \\
\end{array}$ & 2010 & Book & $\begin{array}{l}\text { The BM describes the rationale of how an } \\
\text { organization creates, delivers, and captures } \\
\text { value. }\end{array}$ & $\begin{array}{l}\text { Value Proposition, Customer Segments, } \\
\text { Distribution Channel, Customer Relations, } \\
\text { Revenue Streams, Key Partnerships, Key } \\
\text { Resources, Key Activities, Cost Structures }\end{array}$ \\
\hline $\begin{array}{l}\text { SEDDON, P.B., } \\
\text { LEWIS, G.P., } \\
\text { FREEMAN, P. and } \\
\text { SHANKS, G. }\end{array}$ & $\begin{array}{l}\text { The case for } \\
\text { viewing business } \\
\text { models as } \\
\text { abstractions of } \\
\text { strategy }\end{array}$ & 2004 & $\begin{array}{l}\text { Communications } \\
\text { of AIS }\end{array}$ & $\begin{array}{l}\text { A BM outlines the essential details of a } \\
\text { firm's value proposition for its various } \\
\text { stakeholders and the activity system the firm } \\
\text { uses to create and deliver value to its } \\
\text { customers. }\end{array}$ & Value proposition, Strategy, Value creation \\
\hline $\begin{array}{l}\text { SHAFER, S.M., } \\
\text { SMITH, H.J. and } \\
\text { LINDER, J.C. }\end{array}$ & $\begin{array}{l}\text { The power of } \\
\text { business models }\end{array}$ & 2005 & Business Horizons & $\begin{array}{l}\text { A BM is a representation of a firm's } \\
\text { underlying core logic and strategic choices } \\
\text { for creating and capturing value within a } \\
\text { value network. }\end{array}$ & $\begin{array}{l}\text { Strategic Choices (customer, value proposition, } \\
\text { capabilities/competencies, revenue/pricing, } \\
\text { competitors, output, strategy, branding, } \\
\text { differentiation, mission), Create value } \\
\text { (resources/assets, processes/activities), Value } \\
\text { network (suppliers, customer information, } \\
\text { customer relationship, information flows, } \\
\text { product/service flows), Capture value (cost, } \\
\text { financial aspects, profit) }\end{array}$ \\
\hline TEECE, D.J. & $\begin{array}{l}\text { Business Models, } \\
\text { Business } \\
\text { Strategy and } \\
\text { Innovation }\end{array}$ & 2010 & $\begin{array}{l}\text { Long Range } \\
\text { Planning }\end{array}$ & $\begin{array}{l}\text { A BM articulates the logic, the data, and } \\
\text { other evidence that support a value } \\
\text { proposition for the customer, and a viable } \\
\text { structure of revenues and costs for the } \\
\text { enterprise delivering that value. [...] It's }\end{array}$ & $\begin{array}{l}\text { Value proposition (logic, data, other evidence that } \\
\text { support it), Revenue and cost structure (value } \\
\text { capture) }\end{array}$ \\
\hline
\end{tabular}




\begin{tabular}{|l|l|l|l|l|}
\hline & & & $\begin{array}{l}\text { about the benefit the enterprise will deliver to } \\
\text { customers, how it will organize to do so, and } \\
\text { how it will capture a portion of the value that } \\
\text { it delivers. BM reflects management's } \\
\text { hypothesis about what customers want, how } \\
\text { they want it, and how an enterprise can best } \\
\text { meet those needs and get paid for doing so. }\end{array}$ \\
\hline TIMMERS, P. & $\begin{array}{l}\text { Business Models } \\
\text { for Electronic } \\
\text { Markets }\end{array}$ & 1998 & $\begin{array}{l}\text { A BM is an architecture for the product, } \\
\text { service and information flows, including a } \\
\text { description of the various business actors and } \\
\text { their roles; and a description of the potential } \\
\text { benefits for the various business actors; and a } \\
\text { description of the sources of revenues. }\end{array}$ & $\begin{array}{l}\text { Value chain, Business actors, Benefits for the } \\
\text { actors, Sources of revenues } \\
\text { Markets }\end{array}$ \\
\hline
\end{tabular}


Table 2: Turnover of Loccioni Group for the period 2000-2012

\begin{tabular}{|c|c|c|c|}
\hline Year & Turnover (€) & $\begin{array}{c}\text { Variation in. \% } \\
\text { based on the } \\
\text { prior year }\end{array}$ & $\begin{array}{c}\text { Variation in \% } \\
\text { based on the year } \\
\mathbf{2 0 0 0}\end{array}$ \\
\hline 2000 & 24.000 & - & - \\
2001 & 25.000 & $4,17 \%$ & $4,17 \%$ \\
2002 & 24.000 & $-4,00 \%$ & $0,00 \%$ \\
2003 & 26.000 & $8,33 \%$ & $8,33 \%$ \\
2004 & 27.000 & $3,85 \%$ & $12,50 \%$ \\
2005 & 32.000 & $18,52 \%$ & $33,33 \%$ \\
2006 & 39.500 & $23,44 \%$ & $64,58 \%$ \\
2007 & 44.600 & $12,91 \%$ & $85,83 \%$ \\
2008 & 45.000 & $0,90 \%$ & $87,50 \%$ \\
2009 & 44.400 & $-1,33 \%$ & $85,00 \%$ \\
2010 & 60.500 & $36,26 \%$ & $152,08 \%$ \\
2011 & 61.200 & $1,16 \%$ & $155,00 \%$ \\
2012 & 64.000 & $4,58 \%$ & $166,67 \%$ \\
\hline
\end{tabular}

Table 3: Loccioni's initiatives related to society

\begin{tabular}{|l|l|}
\hline \multicolumn{1}{|c|}{ Initiative } & \multicolumn{1}{|c|}{ Overview } \\
\hline U-Net & $\begin{array}{l}\text { A network created with universities and research centers, including: } \\
\text { Ancona, Camerino, Cassino, Catania, Genoa, Italy, L'Aquila, Luiss, } \\
\text { Macerata, Naples, Perugia, Pisa, Milan Polytechnic, St. Anne, } \\
\text { Columbia (USA), JRC Ispra, Institute CNR Motor, CNR Pisa, Istituto } \\
\text { Boella, TUV Austria TUV Regensburg. }\end{array}$ \\
\hline Bluzone & $\begin{array}{l}\text { A network that includes all the educational and recreational activities } \\
\text { targeting staff members and their families. }\end{array}$ \\
\hline $\begin{array}{l}\text { An area, both physical and metaphorical, that in Loccioni represents } \\
\text { the interface between the world of school and the work. Every year } \\
\text { they hosted 1,000-1,200 students from the fifth grade up to the } \\
\text { postgraduate master for various types of experience: internships, } \\
\text { training, orientation visits and business. }\end{array}$ \\
\hline Silverzone & $\begin{array}{l}\text { Silverzone is a network of experiences and knowledge. "Beautiful" } \\
\text { persons in their sixties and retired that Loccioni met along the way, as } \\
\text { collaborators, as customers, as suppliers, as partners have now an } \\
\text { opportunity to transfer their experience to young people, with } \\
\text { renewed enthusiasm, passion, and fun. }\end{array}$ \\
\hline Start the enterprise & $\begin{array}{l}\text { In this case Loccioni becomes an incubator (providing basic services } \\
\text { for new start-ups). In 30 years they have "born" about 80 companies. }\end{array}$ \\
\hline
\end{tabular}




\begin{tabular}{|c|c|}
\hline & $\begin{array}{l}\text { Loccioni and people who are ready for the jump from the position of } \\
\text { internal employee to that of entrepreneur. }\end{array}$ \\
\hline NetPeople & $\begin{array}{l}\text { Through "NetPeople" Loccioni promotes and integrates various } \\
\text { business networks, local organisations, and research institutions. } \\
\text { NetPeople includes } 10 \text { companies, } 750 \text { employees and } 500 \text { users and } \\
\text { network clients. The mission of the network is to optimize processes } \\
\text { and improve customer products, thanks to a global service, which } \\
\text { finds its basis in consulting activity pre- and post-sales, the possibility } \\
\text { of a co-design with the customer, co-sharing with them information } \\
\text { and knowledge, in the view of technological exchange. }\end{array}$ \\
\hline Nexus & $\begin{array}{l}\text { A multi-sectoral network consisting of local realities that aims to } \\
\text { communicate and interact in order to maximize the territory, and } \\
\text { individual and enterprise knowledge. It consists of } 28 \text { businesses and } \\
550 \text { collaborators. Members of Nexus make numerous trips of } \\
\text { confrontation with other realities of territorial excellence with an aim } \\
\text { to learn and find new opportunities for development. }\end{array}$ \\
\hline Crossworlds & $\begin{array}{l}\text { A network of large international groups, in collaboration with ATA } \\
\text { (Technical Association) and Loccioni, it is to stimulate the transfer of } \\
\text { technologies from automotive to other sectors. }\end{array}$ \\
\hline MARCHEstyle & $\begin{array}{l}\text { The project aims to attract or bring to the territory } 50 \text { talents who } \\
\text { want to change their lives, reconciling their lifestyles on a human scale } \\
\text { of the Marche and pursue the late stage of their business career in the } \\
\text { Loccioni group. They are looking for senior professionals with a lot of } \\
\text { experience. For example, a sixty years manager who wants to spend } \\
\text { his last years before retirement transmitting his or her skills to young } \\
\text { people in a training project is an important resource for Loccioni. }\end{array}$ \\
\hline Land of Value (LOV) & $\begin{array}{l}\text { An enhancement project of the Marche area achieved through } \\
\text { collaboration with accommodation and dining facilities representative } \\
\text { of the local eno-gastronomic heritage. LOV aims to make the } \\
\text { experience by Loccioni a unique and unforgettable moment: let those } \\
\text { who visit the company (over } 8000 \text { visits per year), to share in the same } \\
\text { encounter professionalism and conviviality. }\end{array}$ \\
\hline “LOCCIONI" Editions & $\begin{array}{l}\text { Publications about Loccioni and its business culture published in } \\
\text { collaboration with the Olivetti Historical Archive. }\end{array}$ \\
\hline
\end{tabular}


Table 4: Loccioni's key operational activities

\begin{tabular}{|c|c|}
\hline Competences on demand & $\begin{array}{l}\text { Management structure by vertical markets was abandoned in order } \\
\text { to apply a matrix approach with transversal functions based on the } \\
\text { re-configurability of 'on-demand' competences. }\end{array}$ \\
\hline $\begin{array}{l}\text { Research for Development } \\
\text { ( } 3 \text { years horizon) }\end{array}$ & $\begin{array}{l}\text { Through its } 6 \text { laboratories it carries out research projects of their own } \\
\text { initiative and direct, or at the request of customers and partners, } \\
\text { exploring new territories of industrial innovation. The end of the R \& } \\
\text { D is to add value to projects and "customized solutions" of Loccioni } \\
\text { businesses, and at the same time to ensure that any research activity } \\
\text { will turn into experience and then competence for all. }\end{array}$ \\
\hline $\begin{array}{l}\text { Research for Innovation ( } 5 \\
\text { years horizon) }\end{array}$ & $\begin{array}{l}\text { It is dedicated to the development of studies, conversations and } \\
\text { projects to improve the quality of life. Health care, sustainability, } \\
\text { safety, quality, comfort are some of the key issues that drive the } \\
\text { creation of top-level networks, i.e. scientific community whose aim is } \\
\text { the integration of technology and the continuous and radical } \\
\text { improvement of the same. }\end{array}$ \\
\hline Play Factory & $\begin{array}{l}\text { The new organizational model is based on the book by Hosoe (1968) } \\
\text { "Play Office" whose major topics concern to play in team, return back } \\
\text { to the game, and enjoy the taste of the challenge. }\end{array}$ \\
\hline Play 40 & $\begin{array}{l}\text { A game that has two decks of } 40 \text { cards on which figures, words and } \\
\text { definitions are given in use to all employees and that is used to } \\
\text { enable and facilitate associative mechanisms and the birth of new } \\
\text { ideas. }\end{array}$ \\
\hline Identity Lab & $\begin{array}{l}\text { It is a multidisciplinary laboratory of organisation culture and } \\
\text { communication that develops identity paths, transmits values and } \\
\text { produces sense of "beauty". }\end{array}$ \\
\hline Business Marketing Lab & $\begin{array}{l}\text { An agreement signed in } 2006 \text { between the Loccioni and the Faculty of } \\
\text { Economics "G. Fua" of Ancona for the development and exchange of } \\
\text { scientific know-how. The activities carried out in the laboratory are } \\
\text { mainly of three types: } \\
\text { - market projects for development of customers and potential new } \\
\text { markets; } \\
\text { - market research for understanding of the new reference } \\
\text { scenarios; } \\
\text { - academic research to field-test the application of scientific } \\
\text { models. }\end{array}$ \\
\hline
\end{tabular}

